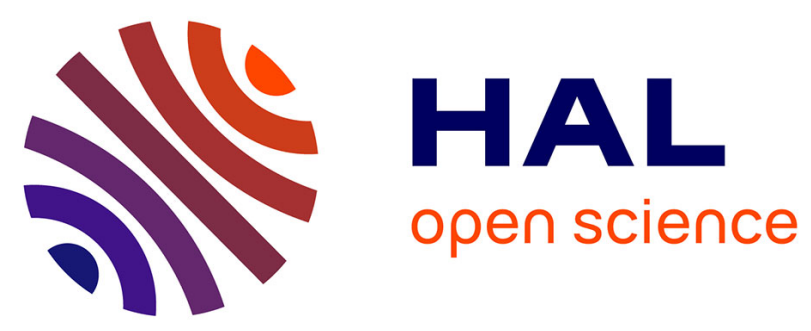

\title{
Behaviour of Atlantic salmon smolts approaching a bypass under light and dark conditions: Importance of fish development
}

Stéphane Tetard, Anthony Maire, Marine Lemaire, Eric de Oliveira, Patrick Martin, Dominique Courret

\section{To cite this version:}

Stéphane Tetard, Anthony Maire, Marine Lemaire, Eric de Oliveira, Patrick Martin, et al.. Behaviour of Atlantic salmon smolts approaching a bypass under light and dark conditions: Importance of fish development. Ecological Engineering, 2019, 131, pp.39-52. 10.1016/j.ecoleng.2019.02.021 . hal02062027

\section{HAL Id: hal-02062027 \\ https: / hal-edf.archives-ouvertes.fr/hal-02062027}

Submitted on 19 Mar 2019

HAL is a multi-disciplinary open access archive for the deposit and dissemination of scientific research documents, whether they are published or not. The documents may come from teaching and research institutions in France or abroad, or from public or private research centers.
L'archive ouverte pluridisciplinaire HAL, est destinée au dépôt et à la diffusion de documents scientifiques de niveau recherche, publiés ou non, émanant des établissements d'enseignement et de recherche français ou étrangers, des laboratoires publics ou privés. 


\title{
Behaviour of Atlantic salmon smolts approaching a bypass under light and dark conditions: importance of fish development
}

\author{
Stéphane TETARD ${ }^{\mathrm{a},{ }^{*}}$, Anthony MAIRE ${ }^{\mathrm{a}}$, Marine LEMAIRE $^{\mathrm{a}, \mathrm{b}}$, Eric \\ DE OLIVEIRA $^{\mathrm{a}}$, Patrick MARTIN $^{\mathrm{c}} \&$ Dominique COURRET $^{\mathrm{d}}$ \\ Ecological Engineering - 2019 - 131 - pp. 39-52 \\ DOI: 10.1016/j.ecoleng.2019.02.021 \\ https://www.sciencedirect.com/science/article/pii/S0925857419300734
}

\begin{abstract}
a EDF R\&D LNHE - Laboratoire National d'Hydraulique et Environnement, 6 quai Watier, 78401 Chatou, France

${ }^{\mathrm{b}}$ UMR CARRTEL INRA, Université de Savoie, 75 avenue de Corzent, BP 511, 74203 Thononles-Bains Cedex, France

${ }^{c}$ CNSS, Larma, 43300 Chanteuges, France

d Agence Française pour la Biodiversité, Pôle Ecohydraulique, AFB-IMFT-Université de Toulouse-CNRS, 2 Allée du professeur Camille Soula, 31400 Toulouse, France

*Corresponding author-E-mail address: stephane.tetard@edf.fr (S. Tétard).
\end{abstract}

\section{Publication History}

Received: 19 September 2018

Revised: 20 February 2019

Accepted: 23 February 2019

Version of record online: 07 March 2019

Issue online: June 2019

NB: This version of the manuscript corresponds to the last version before edition by the journal. Some changes made by the editor afterwards may not be present in this version. See online article on the journal's website for the final version of the article. 


\begin{abstract}
The development of passage systems for migratory fish is crucial to mitigate the impact of river fragmentation. Concerning downstream migration of juvenile salmon (smolts), understanding their behaviour is a key to improving the efficiency of bypass systems. Among devices to improve efficiency, artificial lighting has proved effective in certain situations. Based on (1) recent observations of early migrating smolts where migration was delayed in the Poutès dam reservoir (Allier River, France) and (2) the fact that the implementation of bypass lighting devices was based on experiments involving laterseason migrants, the present study assessed the effect of a lighting device on wild early-migrating smolts. One hundred wild smolts were tagged with acoustic transmitters and their behaviour near the bypass entrance under lit or dark conditions was assessed using 2D acoustic telemetry. A very abrupt change in behaviour around mid-April was observed, which directly affected their response to light. In the first phase of the downstream migration season (before mid-April), lighting significantly reduced the attractiveness of the bypass, while this surprisingly seemed to favour passage: smolts less frequently approached the bypass entry zone but passed through it more frequently. However, in the second phase (after mid-April), lighting attracted and kept the smolts close to the bypass entrance and significantly increased passage, corroborating previous experiments. The present study demonstrated an interaction between the development of migratory fish and their behaviour under lit or dark conditions. It also highlighted the importance of taking account of such behavioural change during the migration season when designing fish passage systems.
\end{abstract}

KEY-WORDS: Acoustic telemetry, artificial light, fragmentation, fishway, Salmo salar, downstream migration.

\title{
1. INTRODUCTION
}

Considered as 'cultural keystones species' (Garibaldi and Turner, 2004), diadromous fish are in decline throughout the world (Limburg and Waldman, 2009). One such species, the Atlantic salmon (Salmo salar), which is the focus of the world's highest profile recreational fishery and the basis of the world's largest aquaculture industries (Verspoor et al., 2008), has undergone general decline. Recruitment of European stock has dropped from nearly 8 million in the early 1970s to about 3 million more recently (Friedland et al., 2009). Atlantic salmon is an anadromous species, with both juveniles and post-spawn adults undertaking long ocean migration (Thorstad et al., 2011). They migrate to forage for one or more years in rich feeding grounds from the Faeroe Islands in the south to the Svalbard archipelago in the north and Barents Sea in the east, with great individual variation (Strøm et al., 2018). Adult salmon then return to their "home" river to spawn in autumn or winter on gravel in swift-flowing water. In some large river systems, adult Atlantic salmon may migrate up to 1,000 km (Lucas and Baras, 2001). After usually one or two years in freshwater, juvenile salmon ('parrs') go through a series of morphological, physiological and behavioural changes (Folmar and Dickhoff, 1980), becoming silvery 'smolts' (Lucas and Baras, 2001), then emigrate to the ocean in spring. Smoltification is controlled by photoperiod and temperature, with migration onset triggered by temperature and sometimes by discharge (Nyqvist et al., 2017). Behavioural changes include increased negative rheotaxis (McCormick et al., 1998), schooling (Folmar and Dickhoff, 1980; McCormick et al., 1998) and decreased agonistic and territorial behaviour (McCormick et al., 
1998). The transition from parr to smolt is progressive, with behavioural changes related to the size and physiological state of the fish (Iwata, 1995; Martin et al., 2012) but also to environmental changes (McCormick et al., 1998).

The causes of the global decline of salmon populations are multiple: habitat degradation (especially damming) (Limburg and Waldman, 2009; Tentelier and Piou, 2011), pollution (Lotze and Milewski, 2004), overfishing (Mota et al., 2016), disease (Okamura et al., 2011), and climate change (Graham and Harrod, 2009; Jonsson and Jonsson, 2009; Todd et al., 2008). Although the collapse of survival rates in marine environments in recent decades has been increasingly pointed out (ICES, 2016; Jonsson and Jonsson, 2004), river fragmentation is often cited as one of the main causes of their decline (Larinier, 2001; Limburg and Waldman, 2009; Lucas and Baras, 2001; Thorstad et al., 2008), as well as confinement to restricted areas (Larinier, 2001; Porcher and Travade, 1992). Nevertheless, it is sometimes difficult to disentangle the impact of obstacles to migration from the other aforementioned human-induced pressures that could act additively, synergistically or even antagonistically (Limburg and Waldman, 2009; Lotze and Milewski, 2004; Segurado et al., 2015). Despite resources allocated to the restoration of longitudinal connectivity (e.g., fishways, dam removal) and the reduction in overfishing in recent years, there has been little improvement in the status of the stock (ICES, 2016). The need to restore longitudinal connectivity in order to facilitate the access of adults to suitable and high-quality habitats and the emigration of smolts to the ocean is especially crucial in the context of climate change (Isaak et al., 2015; Jonsson and Jonsson, 2009). The shifts observed in phenological periods for migratory fish may indeed imply that delayed migration can adversely affect the achievement of their full life-cycle and therefore the long-term survival of salmonid populations (Crozier and Hutchings, 2014; Morita, 2019). The need for remedial measures for both upstream and downstream migration has been recognised for a long time, and fishway construction has increased in the recent decades (Silva et al., 2018). However, the efficiency of fish passage solutions is variable, and low in many cases (Noonan et al., 2012; Roscoe and Hinch, 2010). Specifically, downstream migration issues have been addressed more recently (Larinier and Travade, 2002), efforts having been first devoted to fishways for upstream migration. Moreover, effective fish passages for downstream migration are much more complex to develop, especially for large installations (Larinier and Travade, 2002). Such fishways have been developed on power plants or pumping stations, to prevent fish passing via routes liable to cause direct or delayed mortality (Ferguson et al., 2006; Pracheil et al., 2016). Passage through spillways or over weirs is almost always considered safe (Larinier and Travade, 2002). Nevertheless, the issue of migratory delay remains for all kinds of barrier, whether hydropower (Keefer et al., 2012) or not (Aarestrup and Koed, 2003; Drouineau et al., 2017).

Downstream passage solutions often aim at stopping fish at the intake screen by sufficiently narrow bar spacing before guiding them towards a surface bypass (Larinier and Travade, 2002; Nyqvist et al., 2018). Stopping fish does not always mean that the fish are physically blocked. Screens can act as behavioural barriers (Larinier and Travade, 2002) by altering the hydrodynamic or visual environment (Enders et al., 2012; Swanson et al., 2004). Consequently, at first, many bypasses, the dimensions, discharge and location of which had been optimised, were associated with existing conventional trashracks, but had highly variable and sometimes 
poor success (Croze, 2008; Larinier and Boyer-Bernard, 1991a; 1991b; Larinier and Travade, 1999; Ovidio et al., 2017). Retrofitted intakes with fine-spaced low-sloping racks, either inclined or angled, have now proven effective (Nettles and Gloss, 1987; Nyqvist et al., 2018; Tomanova et al., 2017; Tomanova et al., 2018). Non-structural behavioural systems to guide fish with visual, auditory, hydrodynamic or electrical stimuli have also been tested (e.g. Nemeth and Anderson, 1992; Scruton et al., 2003), but no clear solution that can be easily implemented in new locations has been determined (Williams et al., 2012).

For both upstream and downstream migration, understanding the behaviour of migrating smolts is crucial (Williams et al., 2012). Typically, smolts tend to move with the bulk flow (Williams et al., 2012) while also being capable of active swimming, avoiding unsuitable conditions such as rapid changes in water velocity (Enders et al., 2009; Kemp and Williams, 2009). Smolts predominantly migrate at night, but are increasingly observed during the day later in the migration period (McCormick et al., 1998), the ratio of day and night passages balancing out by the end of the migration season (Ibbotson et al., 2006; Larinier and Boyer-Bernard, 1991a; 1991b). This transition is possibly related to a migratory urge, as suggested by Nyqvist et al. (2017), who also observed that migration in a free-flowing river stretch was faster for latereleased fish than for fish released earlier in the migratory season. Along with all these behavioural changes, McLennan et al. (2018) found that the survival rate of smolts exiting a reservoir was higher for early than for late migrants.

Considering that fish are visually sensitive animals (Fernald, 1988) and that light stimuli are easy and cheap to produce, light has often been used, as either an attractor to guide fish towards bypasses (e.g., Gessel et al., 1991; Larinier and Boyer-Bernard, 1991a; 1991b; Mueller and Simmons, 2008; Nestler et al., 1995; Ploskey et al., 1995) or a deterrent to draw them away from turbines (e.g., Hamel et al., 2008; Johnson et al., 2005; Perry et al., 2014). As a deterrent, strobe lights proved effective in some situations (Hamel et al., 2008; Johnson et al., 2005). Nemeth and Anderson (1992) observed that, for juvenile Coho and Chinook salmon, differences in light intensity could change stimulus valence from attraction to repulsion. Juvenile salmonids would avoid or be startled when exposed to light levels corresponding to daylight conditions or near 400 lux (Mueller and Simmons, 2008). In laboratory experiments, Hansen et al. (2018) suggested that repulsion was not determined by light intensity alone but rather by a combination with wavelength. Furthermore, light seems to affect the behaviour of smolts in areas of flow acceleration, and the response seems to be variable and species-dependent (Kemp et al., 2006; Vowles et al., 2014). Riley et al. (2012) even suggested that, as several studies recognised two separate stages in salmon smolt migratory behaviour (i.e., solitary movement followed by schooling), artificial lighting could elicit a variable response in smolt migratory behaviour. This great complexity of light stimulation as attractor may explain why it was shown to enh ance efficiency in some bypasses (Croze, 2008; Larinier and Boyer-Bernard, 1991b) while having no effect in others (Chanseau et al., 1999; Larinier and Boyer-Bernard, 1991a).

In the upper Allier River (France) upstream of the Poutès dam, Atlantic salmon smolts begin their seaward migration about $900 \mathrm{~km}$ from the ocean. Recent studies with a rotary screw trap positioned only $1.5 \mathrm{~km}$ upstream of the Poutès reservoir (CNSS, 2013; 2014) found much earlier migration sparking than usually recorded at the videocounting station of the Poutès dam bypass since 1999 (Bach et al., 2015), suggesting a considerable delay caused by the Poutès 
dam. Indeed, 88\% and 95\% of smolt total catches were made in March in 2013 and 2014, respectively, whereas most of the fish usually pass the Poutès bypass between mid-April and mid-May (Bach et al., 2015). Specifically, the wild individuals caught were morphologically very different from the silvery smolts traditionally observed later in the migration season, looking more like parrs or slightly silvery smolts. Furthermore, a telemetry experiment conducted to study the behaviour of these early migrating smolts (Tétard et al., 2016) showed a significant delay (mean residence time in the reservoir of 13.7 days) in relation to a very abrupt change in the behaviour of the fish, which considerably increased their activity after mid-April (see Appendix A.1 for details).

The surface bypass of Poutès dam is lit by a mercury lamp every year during the migration season, since this device was experimentally found to be effective (Larinier and Boyer-Bernard, 1991b). Larinier and Boyer-Bernard (1991b) showed that 3 to 8 times as many smolts passed the bypass during lit nights as when the lighting was switched off. However, these experiments were essentially conducted during April and May, at a time when most of the fish would normally be much further downstream of Poutès. This is why, in the light of recent observations that smolts migrate much earlier in the season, with very distinct behaviour and difficulty in passing the dam at Poutès, it seemed worth re-examining the effect of bypass lighting on smolt behaviour. The objective of the present study was therefore to assess the nocturnal behaviour of wild smolts approaching the Poutès dam and its bypass, in presence or absence of artificial lighting and in relation to the period in the migration season.

\section{MATERIAL AND METHODS}

\subsection{Study area}

The Loire River is $1,012 \mathrm{~km}$ long and has a drainage area of $117,000 \mathrm{~km}^{2}$. It is the longest river system in Europe in which spawning migration of Atlantic salmon still occurs (Cuinat, 1988). The Allier River, its main tributary (Figure 1), presents the most functional spawning zones for Atlantic salmon (Baisez et al., 2011). The Poutès dam is located $861 \mathrm{~km}$ from the estuary, in a crucial zone for the salmon population: areas upstream of Poutès represent about $60 \%$ of the potential juvenile production of the Allier River (Minster and Bomassi, 1999).

The dam is $18 \mathrm{~m}$ high and $85 \mathrm{~m}$ wide and bypasses a river stretch of the Allier River of $10 \mathrm{~km}$ from Poutès to Monistrol d'Allier, creating a reservoir of $2.4 \mathrm{Mm}^{3}$ that expands over $3.5 \mathrm{~km}$ (mean water residence time of 1.67 days). Three spillways (14 m long each) discharge floodwater. The mean annual discharge of the Allier River in Monistrol d'Allier is $16.6 \mathrm{~m}^{3} . \mathrm{s}^{-1}$. The maximum diverted flow to the Monistrol d'Allier powerhouse is $28 \mathrm{~m}^{3} \cdot \mathrm{s}^{-1}$. The powerhouse is equipped with three Francis turbines (\#1/2: $16 \mathrm{~m}^{3} \cdot \mathrm{s}^{-1}$; \#3: $3 \mathrm{~m}^{3} \cdot \mathrm{s}^{-1}$ ). The legal minimum flow in the bypass stretch downstream of the dam is 4 to $5 \mathrm{~m}^{3} \cdot \mathrm{s}^{-1}$, depending on the season.

The rack ( $24 \mathrm{~m}$ wide, $5.7 \mathrm{~m}$ high) is located on the left bank between 7 and $13 \mathrm{~m}$ below the surface, and has a gap-width of $3 \mathrm{~cm}$ (see Appendix A.2 for details). A surface bypass, operating from March to June, is located at the downstream end of the rack. The entrance of the bypass consists of a weir designed to provide progressive acceleration of flow from the entrance 
towards the weir crest that controls the discharge $\left(0.5 \mathrm{~m} \cdot \mathrm{s}^{-1} \cdot \mathrm{m}^{-1}\right)$, in order to reduce the reluctance of smolts to pass through (length of $2.4 \mathrm{~m}$, progressive width reduction of from 3.6 $\mathrm{m}$ at the entrance to $2.3 \mathrm{~m}$, and progressive depth reduction from $1.1 \mathrm{~m}$ at the entrance to 0.6 m) (see Appendix A.2 for pictures). It is mounted on a gate automatically regulated according to water level to ensure a continuous flow of $2 \mathrm{~m}^{3} \cdot \mathrm{s}^{-1}$, representing $7.1 \%$ of the maximum turbined flow. The bypass is lit by a $50 \mathrm{~W}$ mercury vapour lamp positioned $3 \mathrm{~m}$ above the entrance and creating a halo of light of approximately $3 \mathrm{~m}$ diameter.

For upstream migration, a fish lift is raised every two hours throughout the year. Both fish passage solutions (bypass and lift) are video-monitored by the LOGRAMI association.

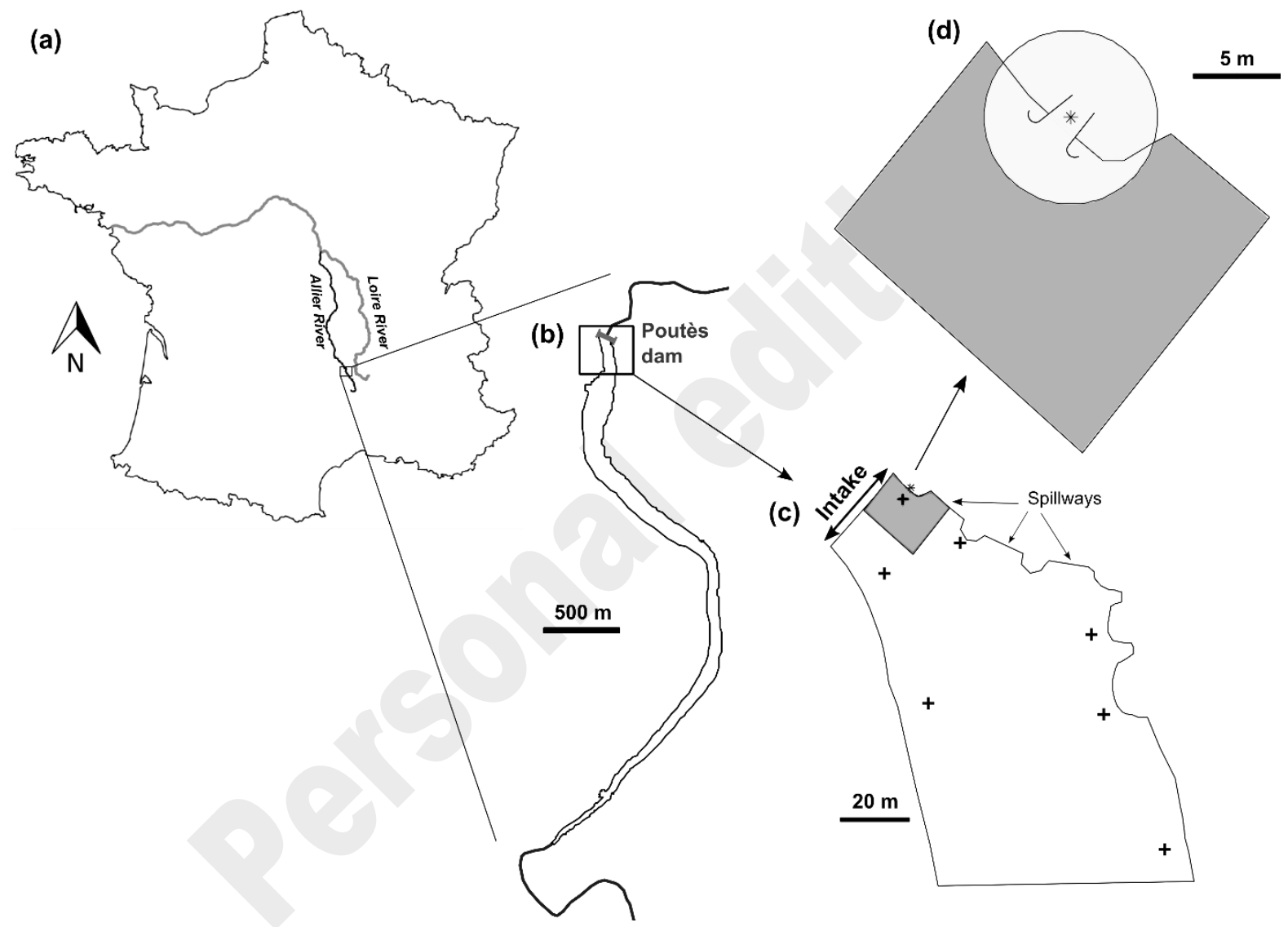

Figure 1. Location of the Poutès dam $(a, b)$ and boundaries of movement zones $(c, d)$. (b) Poutès reservoir on which the "dam zone" is framed, (c) "dam zone" with, in dark grey, the "approach zone", and (d) "approach zone" where the "entry zone" is shown by a light grey circle. The zoom shows the bypass entrance, with its centre (i.e., the lamp) marked by an asterisk. The crosses indicate the hydrophones in the dam zone.

\subsection{Telemetry array and position calculation}

To study the behaviour of smolts approaching the Poutès dam and the passages through the bypass, 11 WHS4000 hydrophones (Lotek Wireless Inc. ()) were used. Seven hydrophones were installed in the dam area to track fish movement up to approximately $80 \mathrm{~m}$ upstream of the dam (Figure 1). Four hydrophones were installed in the bypass stretch $300 \mathrm{~m}$ downstream 
of the dam to confirm passage through the bypass. The hydrophones were mounted on $1 \mathrm{~m}$ PVC tubes anchored on $25 \mathrm{~kg}$ concrete bases and attached to the bank by ropes. Precise GPS location (precision of $0.3 \mathrm{~m}$ ) of the hydrophones was retrieved with a differential GPS (Leica®).

Position in the dam area was calculated using UMAP V1.3.1 (Lotek Wireless Inc. ${ }^{\circledR}$ ), in the $\mathrm{x}$ and y planes. Position data were post-processed using a DOP (Dilution of Precision, UMAP parameter) of 0.3 which kept $68.7 \%$ of the calculated positions. A preliminary survey was conducted to assess location probability (i.e., proportion of tag transmissions that resulted in a calculated position) and positioning error (i.e., Euclidian distance between calculated and actual positions of the tag) following Roy et al. (2014). Mean location probability was $47.6 \%$ and median positioning error $1.1 \mathrm{~m}$, comparable to the results of other studies (Bergé et al., 2012; Núñez-Rodríguez et al., 2018; Roy et al., 2014).

\subsection{Fish catching and tagging}

Wild smolts were caught by a rotary screw trap about $1.5 \mathrm{~km}$ upstream of the reservoir. Based on mark-recapture calibration studies, mean trapping efficiency was estimated at $6.5 \%$ (CNSS, 2014). The trap was checked every morning from $9^{\text {th }}$ March 2015 . Before tagging, fish were anaesthetised in phenoxyethanol solution at $0.3 \mathrm{ml} . \mathrm{L}^{-1}$. Once anaesthetised, fish were measured (total length), weighed and tagged. The acoustic tags were carefully inserted into the body cavity via a lateral incision. Closure used surgical glue. JSAT L-AMT-1.421 tags (10.5 mm long, $5.2 \mathrm{~mm}$ wide, Lotek W ireless Inc. $\left.{ }^{\circledR}\right)$ were used, weighing $0.32 \mathrm{~g}$ in air. Transmitters were programmed to emit a unique individually recognizable coded acoustic signal every 5 seconds. Their weights in air amounted to less than $2 \%$ of fish body weight, as recommended by Winter (1996). After recovering from the anaesthesia, fish were released $3 \mathrm{~km}$ upstream of the reservoir. A total 100 wild smolts were caught and tagged between $14^{\text {th }}$ March and $12^{\text {th }}$ April 2015 , most of which (85\%) were caught between $20^{\text {th }}$ and $29^{\text {th }}$ March. The mean total length of the captured smolts was $150.9 \pm 16.3 \mathrm{~mm}$ and mean body weight $28.1 \pm 9.4 \mathrm{~g}$.

\subsection{Study zones, lighting protocol and periods of smolt activity}

In order to pass a dam, fish must traverse the forebay and locate a passage route (Nyqvist et al., 2016). However, locating a passage route does not mean that the fish will in fact pass the dam, and passage failures are regularly observed with upstream and downstream fishways (Nyqvist et al., 2016; Williams et al., 2012). To study the influence of bypass lighting on smolt behaviour, three zones were defined: 'dam zone', 'approach zone' and 'entry zone' (Figure 1). For the 'approach' and 'dam' zones, we defined an 'attempt" in a zone as a presence in that zone (i.e., all detections within the zone). To distinguish between different "attempts", time thresholds between two consecutive detections in each zone were set according to the distribution of intervals between consecutive detections within the zone (Castro-Santos and Perry, 2012). These thresholds were set at 30 minutes and 2 minutes for the 'dam zone' and 'approach zone', respectively. The "dam zone" corresponded to the whole detection area of the hydrophones, and identified "attempts" at the dam, since a previous study showed that smolts performed many back and forth movements in the reservoir (Tétard et al., 2016). This zone extended over a hundred meters upstream of the dam (Figure 1.c). Given the relatively long distance to the 
bypass and the inclination of the lamp, it was hypothesised that entries into this zone are not under the influence of lighting. The "approach zone" was a rectangular area framing the entrance of the bypass (Figure 1.d) and included the second half of the intake. It extended 19 $\mathrm{m}$ from the intake and $17 \mathrm{~m}$ from the dam (see Appendix A.3). Smolts' nocturnal attempts in this zone were analysed according to the period in the migration season (i.e., before versus after mid-April) and the bypass lighting mode (i.e. on versus off) and may illustrate remote attraction effect of the lighting.

As mentioned in the Introduction, the first part of this telemetry project studied the behaviour of smolts at a larger scale and highlighted a very abrupt change in behaviour, with a considerable increase in activity after mid-April (Tétard et al., 2016). To distinguish more accurately the two time periods of activity in smolt migratory behaviour that may involve different responses to light, as suggested by Riley et al. (2012), a preliminary analysis was made based on detection in the approach zone (Appendix A.1). Results showed that the cumulative percentage of detection and cumulative percentage of individual smolts detected in the approach zone inflect on $15^{\text {th }}$ April. By that date, $53 \%$ of the tagged fish had already been detected in the approach zone but this accounted for only $19 \%$ of total detections, while $100 \%$ of the tagged smolts had already been released. After $15^{\text {th }}$ April, the number of detections and individual smolts detected increased strongly. Consequently, we constructed a qualitative variable, "period in the migration season", and cut the migration season in two on $15^{\text {th }}$ April. Each attempt in the approach zone before $15^{\text {th }}$ April at midnight was categorised as "Before mid-April" and those that occurred after that date as "After mid-April" (None of the attempts began before $15^{\text {th }}$ April and ended after).

Lastly, the "entry zone", shown as a circle with a radius of $5 \mathrm{~m}$ centred on the middle of the bypass entrance (Figure 1.d), corresponded to the area directly under the influence of the lighting. The choice of a circle of $5 \mathrm{~m}$ radius was based on a trade-off between in situ observation of the halo of light (around $3 \mathrm{~m}$ ) and the smolt positioning calculation error (median, $1.1 \mathrm{~m}$ ).

From $5^{\text {th }}$ March to $29^{\text {th }}$ April 2015, the entrance of the bypass was lit every other night from 6 pm to 8 am (local time). The behaviour of smolts in the three previously defined zones was studied from $14^{\text {th }}$ March: i.e., the date of first release of a tagged smolt. After $29^{\text {th }}$ April, the lighting was switched on continuously until $15^{\text {th }}$ June (which is the usual bypass lighting mode at the Poutès dam).

\subsection{Data analysis}

\subsubsection{Passages and attempts}

Firstly, passages (confirmed by detection in the bypass stretch downstream of the dam) were analysed according to period in the migration season (before versus after mid-April) and bypass lighting mode (on versus off). The time of the fish's last position in the entry zone before passage was used to assign the corresponding period of the day, period in the migration season 
and mode of lighting per passage. To consider exclusively nocturnal passages, only those occurring after the time of astronomical twilight in the evening and before astronomical twilight in the morning (when the geometric centre of the sun reaches $-18^{\circ}$ below the horizon) were counted. Transfer rates between zones, defined as the proportions of individual fish detected in a given zone with respect to those detected in the previous, larger zone were also examined (e.g., proportion of fish detected in the approach zone with respect to those detected in the dam zone, or proportion of fish passing through the bypass with respect to those detected in the entry zone).

Secondly, to examine the remote attraction of the bypass, attempts in the approach zone were analysed by calculating, the mean number of nocturnal attempts in this zone per smolt for each attempt in the dam zone, according to period in the migration season and bypass lighting mode.

Lastly, we tested the sensitivity of the results to the size of the approach zone by reproducing the analyses for a larger zone of $28 \times 31 \mathrm{~m}$ and a smaller one of $17 \times 13 \mathrm{~m}$.

\subsubsection{Smolt behaviour in the approach zone}

This part of the analysis used whole dataset of positions in the approach zone. The influence of bypass lighting mode was assessed according to the distance of fish positions to the bypass entrance. It was hypothesised that, when fish are more or less close to the entrance, passage is more or less favoured by the light above the bypass.

Firstly, the proximity of the fish to the bypass entrance was analysed graphically by plotting raw fish positions according to period and lighting mode. We also applied the Minimum Convex Polygon (MCP) method, which is classically used in spatial ecology to capture the effective living area of an animal, excluding marginal positions (Calenge, 2011). MCP 50 (i.e., the polygon including half of the positions closest to the centre of gravity of the positions) was computed to capture the cloud of nocturnal smolt positions. MCP 50 was considered as the most representative "mean position" of the smolts per period/lighting mode.

Secondly, for each attempt of each smolt in the approach zone, the proportion of positions located in the entry zone was calculated (i.e., within the $5 \mathrm{~m}$-radius circle centred on the middle of the weir; Figure 1.d). This metric makes attempts comparable by taking account of the variability in the number of positions between attempts, thus determining the proportion of positions located near the entrance. However, this metric first revealed that a large number of smolts entered the approach zone without entering the entry zone, leading to many null values. Consequently, two generalised linear models (GLM) were then developed to describe the proportion of positions in the entry zone, following Le Pape et al. (2003): a GLM with a binomial distribution was first fitted to presence/absence values and another GLM with a binomial distribution was then fitted to positive proportions only. Conventional procedures to test for statistical assumptions for GLMs were performed, checking the standardised residual deviance and Cook's distance for leverage of observations in the models. 
All statistical tests were performed using R software (R Development Core Team, 2018) and the maptools (ver. 0.8-30), sp (ver. 1.0-15) and rgdal (ver. 0.8-16) packages.

\section{RESULTS}

\subsection{Smolt passages and attempts}

A total of 60 smolts passed the bypass system during the study period (Figure 2), representing $66 \%$ of smolts detected at least once at the dam.

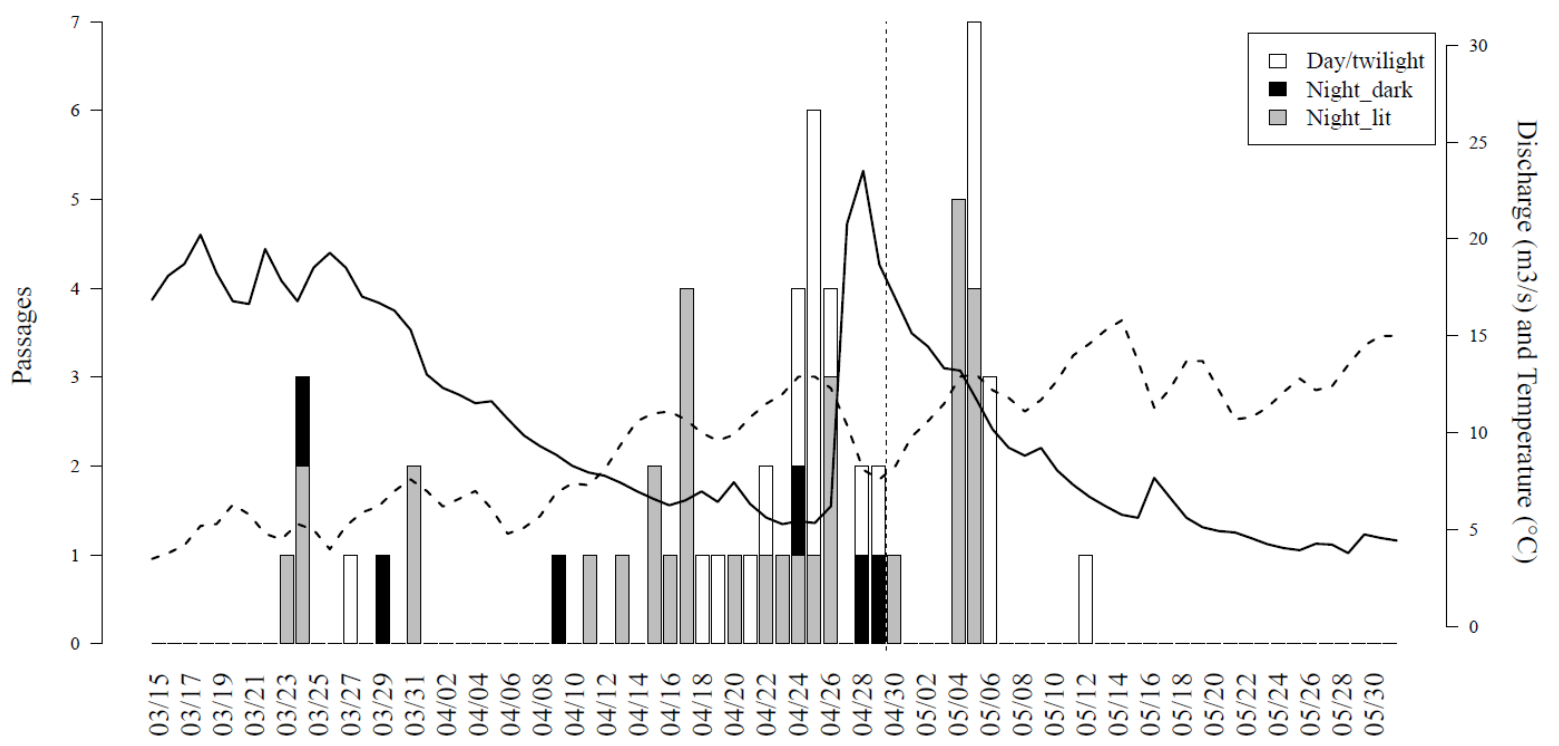

Figure 2. Number of passages of tagged smolts in the bypass according to period of day. Bypass lighting mode is specified for nocturnal passages. Discharge (solid line) and water temperature (dashed line) are also represented. The vertical dashed line represents the end of the period of lighting manipulation.

The mean passage time (i.e., time difference between first detection in the dam zone and last detection before passage) was 11.2 days ( $\mathrm{sd}=11.6$ days; range: $10.7 \mathrm{~min}-43$ days) and showed a decrease over time (Figure 3). 


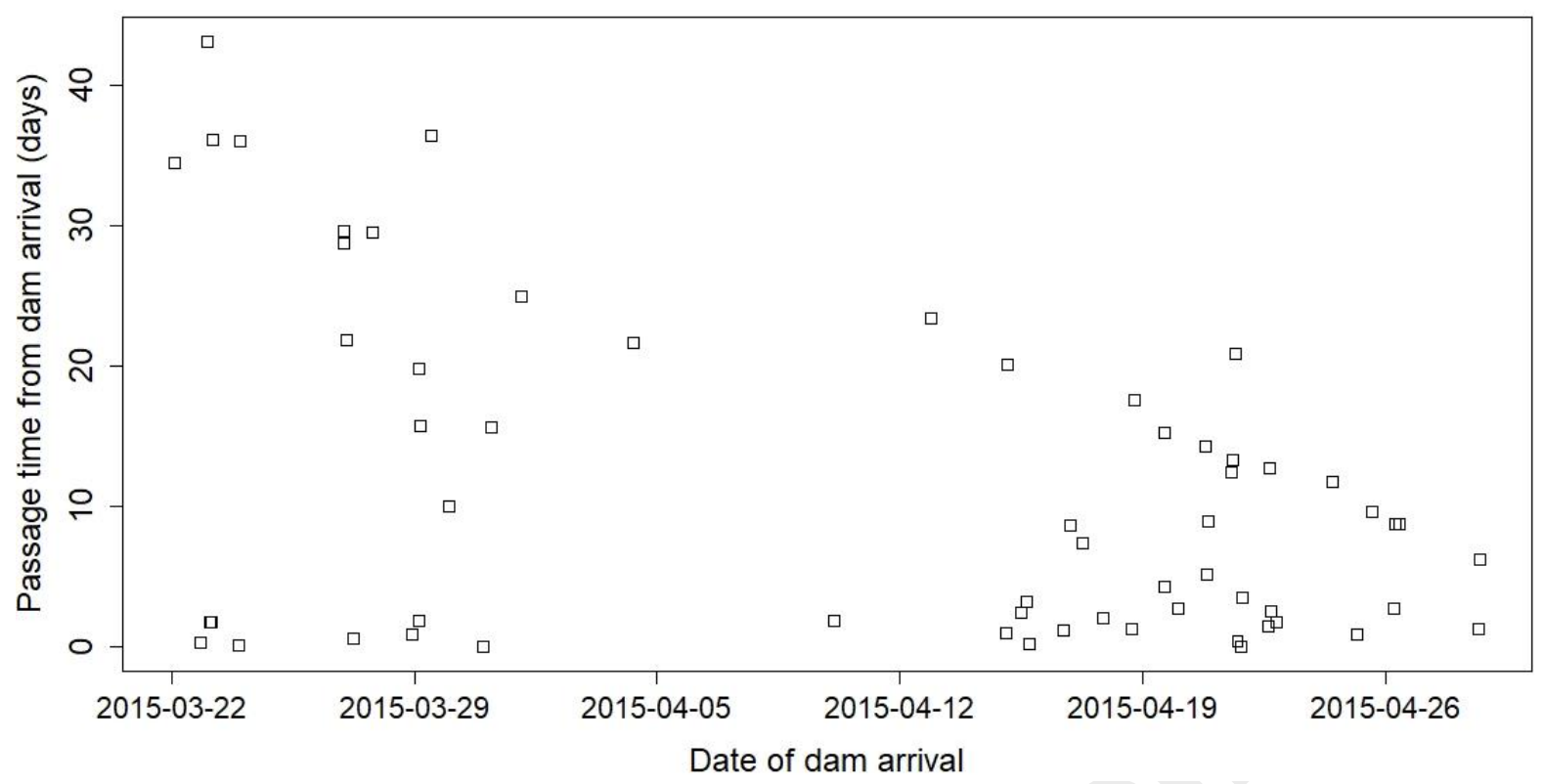

Figure 3. Passage time (days) of tagged smolts according to date of arrival at the dam (i.e., first detection in the dam zone).

From the first release of a tagged smolt on 14th March to the end of the lighting manipulation on $29^{\text {th }}$ April, 44 passages via the bypass were recorded. Nocturnal passages predominated during the lighting manipulation: $66 \%$ of the passages were nocturnal, $20 \%$ were diurnal and $14 \%$ during twilight. However, daytime and twilight passages increased greatly after mid-April, with 1 day or twilight passage before versus 14 after $15^{\text {th }}$ April, representing 9\% and $42 \%$ of the total passages of each period, respectively. For the 29 nocturnal passages during the period of lighting manipulation (Table 1), there was a clear predominance of passages when the bypass was lit: 6 passages in dark conditions versus 23 in lit conditions, representing $21 \%$ and $79 \%$ of total passages, respectively. The proportion of passages in lit condition was higher after midApril: 7 passages in lit condition before versus 16 after mid-April, representing 70\% and 84\% of total passages, respectively; however this difference was not statistically significant $\left(\chi^{2}=\right.$ $0.17, \mathrm{p}=0.68$ ) indicating independence between period in the migration season and bypass lighting mode. The number of passages did not correlated with temperature or river discharge level (Spearman test, $\rho=0.13, \mathrm{p}=0.24$ and $\rho=0.02, \mathrm{p}=0.83$, respectively). Transfer rates between zones during the period of lighting manipulation are presented in Table 1 . The proportion of fish detected in the approach zone with respect to the dam zone was higher when the lighting was switched off in both periods in the migrating season. None of these differences were significant $\left(\chi^{2}=2.4, p=0.12\right.$ and $\chi^{2}=0.79, p=0.37$, respectively). The proportion of fish detected in the entry zone with respect to the approach zone was higher before $15^{\text {th }}$ April but lower after when the lighting was switched off. Again, none of these differences were significant $\left(\chi^{2}=1.19, p=0.28\right.$ and $\chi^{2}=2.12, p=0.12$, respectively). For both periods, the proportion of fish passing with respect to those detected the entry zone was, however, significantly higher when the lighting was switched on $\left(\chi^{2}=5.7, p<0.05\right.$ and $\chi^{2}=8.7, p<0.01$, respectively). About 4 times as many smolts passed during lit as unlit nights in both periods. 
Table 1. Comparison of the number of individual smolts detected in each zone and transfer rates between zones according to period in the migration season and bypass lighting mode. For dam and approach zones, cumulated attempts are also reported.

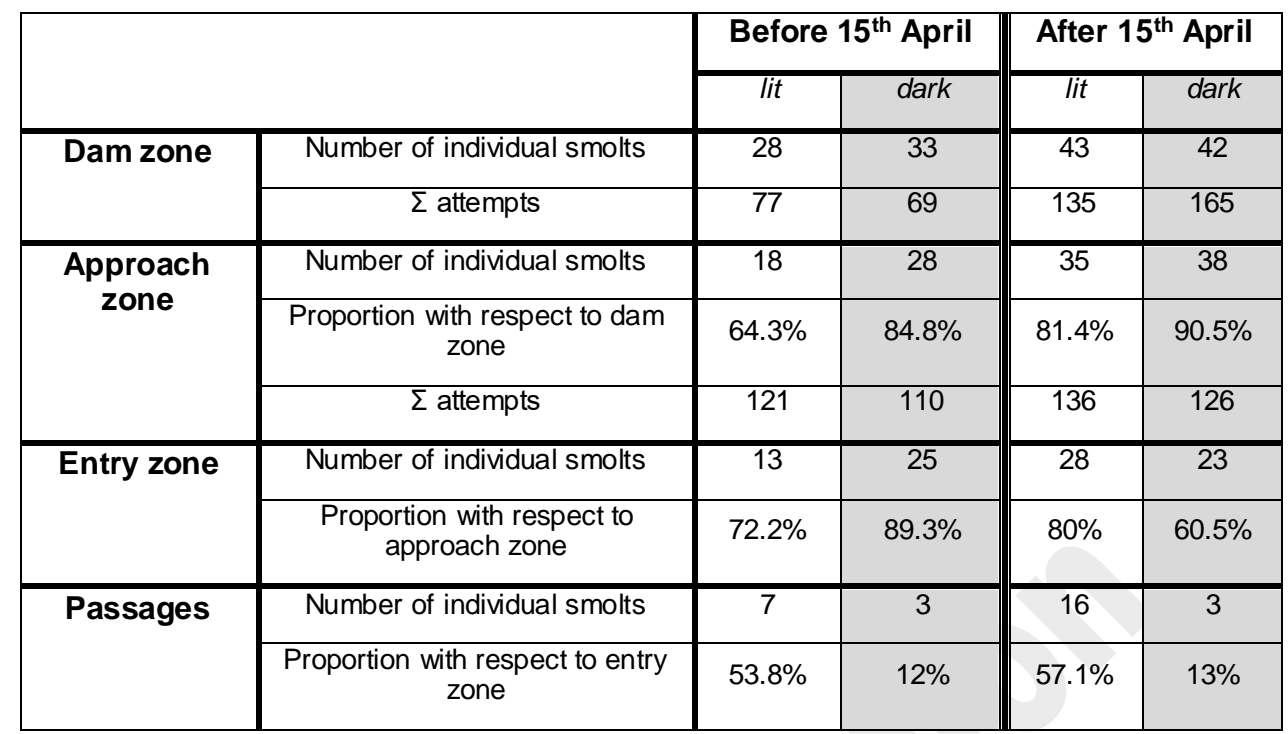

During the study period, there were 446 and 493 nocturnal attempts in the dam zone and approach zone, respectively (Table 1). The lighting protocol applied here enabled the behaviour of smolts near a bypass to be sampled evenly during the migration season, in terms both of number of smolts and of number of attempts. Regardless of the period in the migration season, the mean number of attempts in the approach zone with respect to attempts in the dam zone was higher when the bypass entrance lighting was switched off (Figure 4) but, in both cases, the difference was not significant (Mann-Whitney, $\mathrm{W}=343.5, \mathrm{p}_{\text {before }}=0.08$ and $\mathrm{W}=709, \mathrm{p}_{\text {after }}=$ $0.08)$.

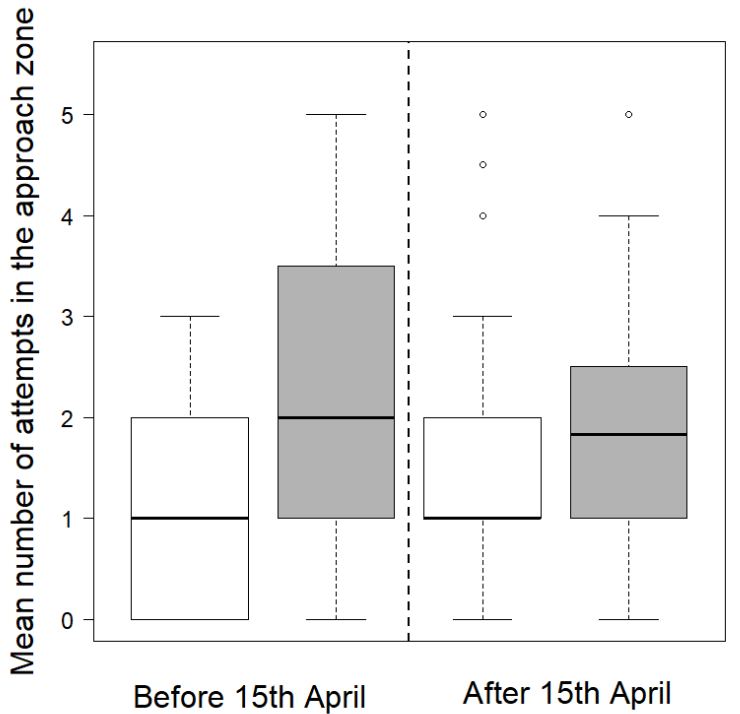

Figure 4. Boxplots of the mean number of nocturnal attempts in the approach zone for each smolt and for each attempt in the dam zone in each configuration of lighting and period within the migration season. White and grey boxes correspond to entrance lighting switched on or off, respectively. For visual purposes, several outliers are not represented. 
For the two other sizes of approach zone tested, there was a slightly higher mean number of attempts when the lighting was switched off (see Appendix A.3 for details). However, the differences in mean number of attempts in the approach zone were again not significant, except for the largest approach zone $(28 \times 31 \mathrm{~m})$ before $15^{\text {th }}$ April (Mann-Whitney, $\left.\mathrm{W}=327, \mathrm{p}<0.05\right)$.

\subsection{Smolt behaviour in the approach zone}

\subsubsection{Visual analyses}

Smolt positions were evenly distributed within the approach zone when the lighting was switched off (Figure 5.b.). When the entrance was lit (Figure 5.a), position density was lower near the entrance. After $15^{\text {th }}$ April, a strong inverse effect was observed, with a great accumulation of positions in the entry zone when the entrance was lit (Figure 5.c) whereas positions were more evenly distributed when it was not lit (Figure 5.d).
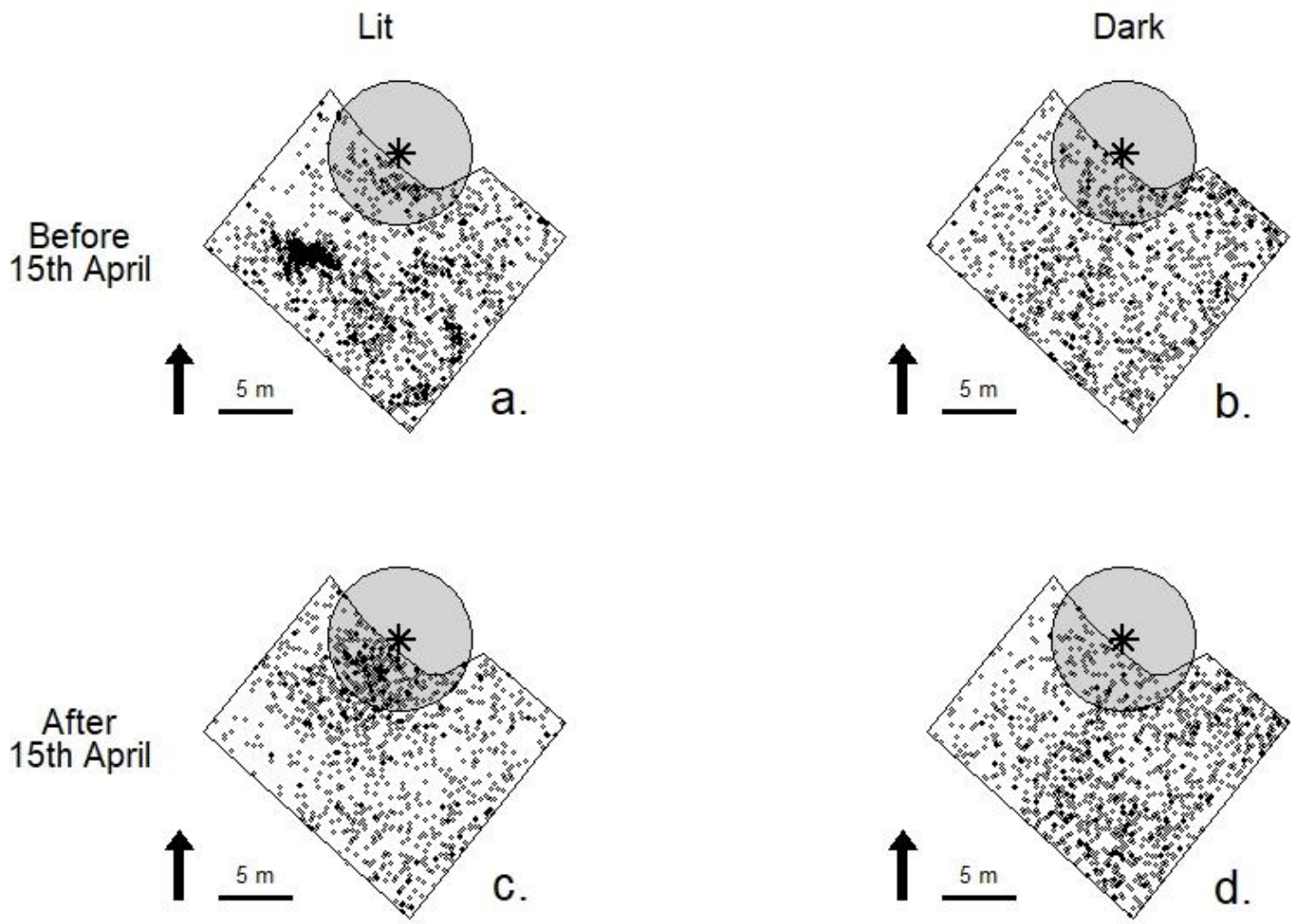

Figure 5. Nocturnal positions of smolts in the approach zone according to period in the migration season and bypass lighting mode. a. Before $15^{\text {th }}$ April - light switched on, b. Before $15^{\text {th }}$ April - light switched off, c. After $15^{\text {th }}$ April - light switched on, d. After $15^{\text {th }}$ April - light switched off. The star represents the entrance to the bypass and the grey circle represents the entry zone ( $5 \mathrm{~m}$ radius). The batch of hundreds of positions in a. comes from a single fish which was located at the same place for 3 hours.

These observations and the potential interaction between period in the migration season and lighting mode are corroborated by the representation of the MCP 50 in Figure 6. These results 
highlight contrasting effects of lighting depending on the period in the migration season: smolts seemed to come closer to the entrance when the entrance was lit, but only after mid-April.

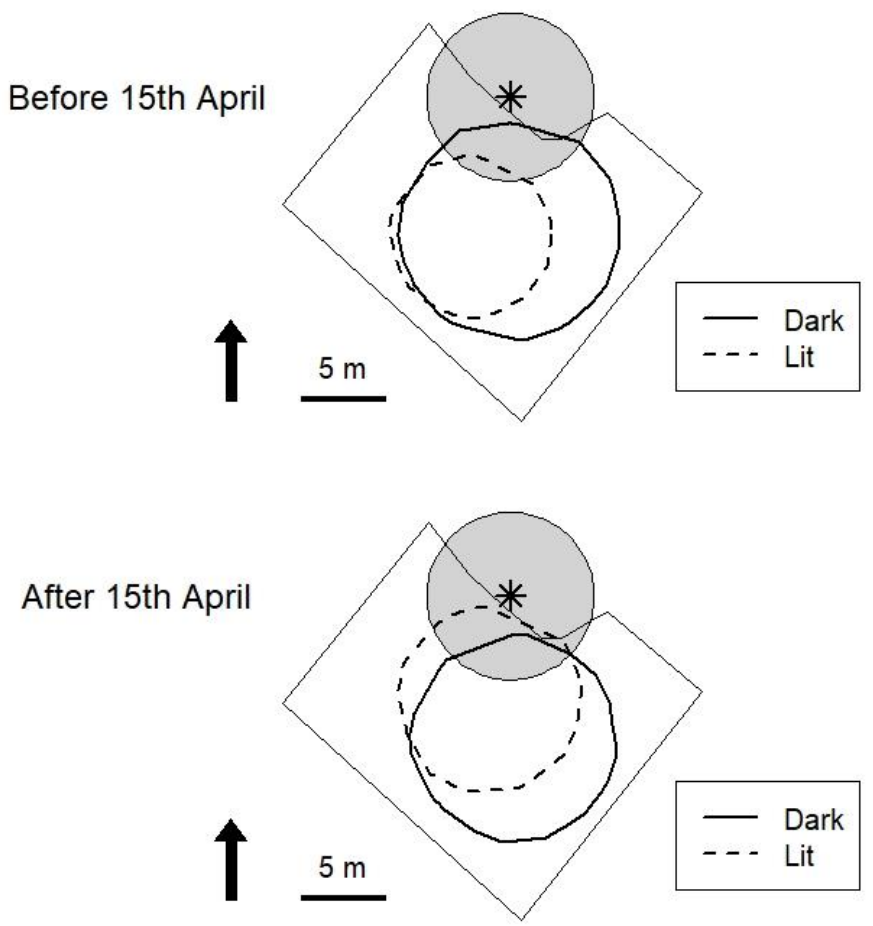

Figure 6. MCP 50 of nocturnal positions of smolts according to bypass lighting mode before $15^{\text {th }}$ April (top) and after $15^{\text {th }}$ April (bottom).

\subsubsection{Testing the interaction between period in the migration season and lighting mode}

A first GLM including both the variable "period in the migration season" (i.e., before or after mid-April) and the variable "bypass lighting mode" (i.e., on or off) and their interaction was fitted to presence/absence values in the entry zone (Table 2). Consistently with the previous visual analyses, the interaction between lighting mode and period was significant $\left(\chi^{2}\right.$, deviance $=15.24, \mathrm{p}<0.001$ ). For this reason, data were separated into two subsets (before and after midApril) for further analyses and two GLMs with binomial distributions were fitted to presence/absence data and positive proportion data.

Table 2. ANOVA of GLM with binomial distribution fitted on presence/absence values.

\begin{tabular}{ccccc}
\hline & Deviance & $\begin{array}{c}\text { Residual } \\
\text { degree of } \\
\text { freedom }\end{array}$ & $\begin{array}{c}\text { Residual } \\
\text { Deviance }\end{array}$ & $\begin{array}{c}\text { P-value } \\
\left(\text { Chi }^{2}\right)\end{array}$ \\
\hline Null Model & 0.1203 & 427 & 594.49 & 0.73 \\
Lighting & 5.1408 & 426 & 589.34 & $\mathrm{p}<0.05$ \\
Period & 15.2434 & 425 & 574.10 & $\mathrm{p}<0.001$ \\
\hline
\end{tabular}




\subsubsection{Influence of lighting mode on smolt behaviour before mid-April}

The presence/absence model confirmed the effect of lighting mode on the probability of smolt presence in the entry zone (Table $3 ; \chi^{2}$, deviance $=8.8, \mathrm{p}<0.01$ ). The coefficient associated with lighting mode was negative (-0.84) and significant (t-test, $\mathrm{Z}=0.79, \mathrm{p}<0.01)$, meaning that the probability of presence of the smolts in the entry zone was significantly lower when the light was switched on before mid-April.

The positive proportion model showed that the effect of lighting mode was not significant (Table 3; $\chi^{2}$, deviance $=0.08, p=0.7832$ ). Thus, smolts entering the entry zone did not seem to be retained in this zone by the lighting before mid-April.

Table 3. ANOVA of presence/absence and positive proportion GLM with binomial distribution before $15^{\text {th }}$ April.

\begin{tabular}{|c|c|c|c|c|c|c|c|c|}
\hline & \multicolumn{4}{|c|}{ 0/1 Binomial Model } & \multicolumn{4}{|c|}{ Positive Proportion Binomial Model } \\
\hline & Deviance & $\begin{array}{c}\text { Residual } \\
\text { DF }\end{array}$ & $\begin{array}{l}\text { Residual } \\
\text { Deviance }\end{array}$ & $\begin{array}{c}\text { P-value } \\
\left(\mathrm{Chi}^{2}\right)\end{array}$ & Deviance & $\begin{array}{c}\text { Residual } \\
\text { DF }\end{array}$ & $\begin{array}{l}\text { Residual } \\
\text { Deviance }\end{array}$ & $\begin{array}{c}\text { P-value } \\
\left(\mathrm{Chi}^{2}\right)\end{array}$ \\
\hline Null Model & & 208 & 286.24 & & & 87 & 117.06 & \\
\hline Lighting mode & 8.7923 & 207 & 277.44 & $P<0.01$ & 0.0757 & 86 & 116.98 & 0.7832 \\
\hline
\end{tabular}

\subsubsection{Influence of lighting mode on smolt behaviour after mid-April}

The presence/absence model showed a significant effect of lighting mode on the probability of smolt presence in the entry zone (Table 4; $\chi^{2}$, deviance $=6.5, \mathrm{p}<0.05$ ). The coefficient associated with lighting mode was positive $(0.70)$ and significant (t-test, $\mathrm{Z}=2.53, \mathrm{p}=0.01$ ), meaning that the probability of presence of smolts in the entry zone was significantly higher when the light was switched on after mid-April.

The positive proportion model showed that the effect of lighting mode was significant (Table 4; $\chi^{2}$, deviance $=48.4, \mathrm{p}<0.001$ ). The coefficient associated with lighting mode indicated a positive (0.89) and significant (t-test, $\mathrm{Z}=6.8, \mathrm{p}<0.001)$ relationship. Consequently, lighting the entrance significantly increased the proportion of smolt positions in the entry zone during smolt attempts in the approach zone.

Table 4. ANOVA of presence/absence and positive proportion GLM with binomial distribution after $15^{\text {th }}$ April.

\begin{tabular}{lcccccccc}
\hline & \multicolumn{3}{c}{ 0/1 Binomial Model } & \multicolumn{3}{c}{ Positive Proportion Binomial Model } \\
\cline { 2 - 9 } & Deviance & $\begin{array}{c}\text { Residual } \\
\text { DF }\end{array}$ & $\begin{array}{c}\text { Residual } \\
\text { Deviance }\end{array}$ & $\begin{array}{c}\text { P-value } \\
\left(\text { Chi }^{2}\right)\end{array}$ & Deviance & $\begin{array}{c}\text { Residual } \\
\text { DF }\end{array}$ & $\begin{array}{c}\text { Residual } \\
\text { Deviance }\end{array}$ & $\begin{array}{c}\text { P-value } \\
\left(\text { Chi }^{2}\right)\end{array}$ \\
\cline { 2 - 10 } Lull Model & 219 & 303.16 & & & 118 & 215.19 & \\
\hline
\end{tabular}




\section{DISCUSSION}

This study confirmed that a notable change in the behaviour of migrating smolts occurs during the season, as previously shown in situ (Ibbotson et al., 2006; Nyqvist et al., 2017; Tétard et al., 2016) and in laboratory experiments (Martin et al., 2012). However, the study further showed that this behavioural change seems to directly influence the interaction between fish behaviour and bypass lighting, thus impacting bypass attractiveness (i.e., the tendency of fish to enter the area near the entrance of the fishway).

Before mid-April, when smolt activity is lower, there was a lower probability of entering the entry zone when lit, which probably reflected a decrease in the close-range attractiveness of the bypass. Remote attractiveness, studied as the mean number of attempts in the approach zone for each attempt in the dam zone, did not show any significant difference between lighting conditions except for the analysis involving the largest approach zone $(28 \times 31 \mathrm{~m})$ before midApril, where the mean number of attempts in the approach zone was higher when the bypass lighting was switched off. However, this number was also higher, although non-significantly, in all other cases. This could reflect a deterrent effect of lighting on remote attractiveness for early season migrants, although complementary studies using other metrics are needed to disentangle the remote effect of lighting.

These results seem consistent with observations of the movements of early smolts, which show a nocturnal migratory behaviour at the beginning of the migration season (Ibbotson et al., 2006; Larinier and Boyer-Bernard, 1991a; McCormick et al., 1998). Regarding the specific case of the Allier River, Martin et al. (2012) showed that smolts exhibited positive rheotactic behaviour with no net movement at the beginning of the migration season; but then increasing daytime introduced a stimulation by natural light. This was suggested by a contrast between diurnal and nocturnal swimming speed, which began to appear around mid-March but greatly increased in April. An increase in swimming speed throughout the season was also observed in situ (Nyqvist et al., 2017). Thus, predominance of nocturnal migration and the absence of swimming stimulation by light, which may be due to lower retinal adaptation from pre-smolt to smolt (Alexander et al., 1994; Hoar et al., 1957), may explain why smolts were not attracted remotely by the light before mid-April. However, our data suggested that there was not only an absence of attraction by light: smolts were also more reluctant to enter the entry zone during attempts in the approach zone at the beginning of the migration period when the bypass entrance was lit. This phenomenon suggests a deterrent effect of the artificial light stimulus, as previously observed in situ with Atlantic salmon smolts (Riley et al., 2012) and in experimental conditions with Chinook salmon encountering accelerating flow (Vowles et al., 2014). Thus, early migrating smolts, moving predominantly at night, would be more likely to show stronger avoidance of light.

Surprisingly, the results concerning passages suggested a positive influence of bypass lighting on passages in the early migration season. More passages through the bypass were counted when the lighting was switched on: 7 when lit versus 3 passages when dark. Moreover, the proportion of fish passing with respect to those detected in the entry zone was significantly higher when the lighting was switched on, throughout the migration season (Table 1). This differential influence of lighting on approach and passage behaviours could be explained by the 
combination of visual and hydrodynamic stimuli in the area close to the bypass entrance, eliciting a differential response of fish in that zone, whereas the hydrodynamic cue is barely perceptible in the reservoir. However, this seems to contradict observations that some salmonid species (Chinook salmon and brown trout) exhibit elevated avoidance behaviour on encountering accelerating flows under lit conditions (Vowles and Kemp, 2012; Vowles et al., 2014). Kemp et al. (2006) reported that behavioural responses to velocity and depth gradients and light condition varied between species. Therefore, as suggested by Riley et al. (2012), comparison between studies must be cautious if the species, the migration phase and levels and types of lighting differ. Moreover, regardless of whether bypass lighting is attracting or deterring smolts close to the bypass entrance, it could induce them to form schools and enhance their exploration activity, as observed by Kemp and Williams (2009) under experimental conditions. Conversely, in darkness, fish maintain their positions against the flow (Kemp and Williams, 2009). Although the stimulus itself may be quite repulsive for early smolts, they may be more likely to pass under lit conditions in relation to enhanced exploration activity. Additionally, lighting could help the smolts enter the bypass, but only after a retinal adaptation period: salmonid retinal adaptation to light takes time (more than 15 minutes according to Brett and Ali, 1958), which would explain the initial repulsive effect of lighting. Our approach confirmed that the behaviours of approach and of passage involve different mechanisms, and that some aspects remain unclear. A fine-scale analysis of smolts' trajectories using trajectometry methods would allow better understanding of the role of light in the passage mechanism in situ.

After mid-April, when smolts are much more active, lighting does not seem to have any influence on the remote attractiveness of the bypass. Surprisingly, Larinier and Boyer-Bernard (1991b) showed a remote attraction of smolts at the Poutès dam using a mercury hand-lamp: they were able to experimentally attract smolts from the opposite bank (60-80 m away) after 10-12 minutes by aiming the lamp at the water at full power; the smolts went away again after 20-30 minutes of lighting but could be attracted back if the lamp was switched off for a moment then relit. This could be one explanation why the present protocol, with night-long lighting, did not enhance the remote attractiveness of the bypass. However, Larinier and Boyer-Bernard (1991b) used lamps of 250 and $400 \mathrm{~W}$, while a less powerful lamp of $50 \mathrm{~W}$ was used in our study, which could also explain the difference in response. Conversely, bypass lighting significantly increased the probability of smolt presence and retention in the entry zone after mid-April. The number of passages in the bypass was also 5 fold higher when the lighting was switched on: 16 in lit condition, 3 in dark condition. This significant influence of lighting at the Poutès dam is probably linked to very low flow velocities in the surface layer of the forebay (quite a large reservoir with a deep intake). These results are consistent with other studies where smolts proved to be attracted by dim mercury lights (Larinier and Boyer-Bernard, 1991b; Nemeth and Anderson, 1992) and with the fact that many bypass systems in the Columbia Basin (USA) use artificial light to attract migratory fish (Mueller and Simmons, 2008).

Although high passage rates reflect a positive effect of artificial lighting, the present spatial analysis highlighted retention in the entry zone after mid-April. An ideal passage solution should allow quick and safe passage for migratory fish, which should not be retained anywhere. However, in large reservoirs, flow patterns can be barely perceptible for fish, making them 
disoriented. Moreover, fish can effortlessly stay in the reservoir because of low flow velocities and could become "lost" because they have not explored the "right" zone in order to pass. Consequently, there is often a trade-off between (i) retaining fish in the right zone to give them more opportunities to pass and (ii) the risk of retaining fish in a zone where they should not be retained but should quickly pass. Again, these is far from optimal conditions for quick and efficient passage, but this is the on-the-field issue in many complex situations, especially those involving big dams and large reservoirs such as at Poutès.

The present findings of a progressive switch from avoidance to attraction by light over the migration season corroborate the study by Nemeth and Anderson (1992), who stated that mercury light may increase fish guidance if fish swim actively but may inhibit it for passively swimming fish. Therefore, a successful design for a downstream bypass system would need precise understanding of fish behaviour and reactions to stimuli when approaching an obstacle. Williams et al. (2012) argued that research to develop passage systems requires using fish actually that are in a positive migratory phase, in order to understand how they react to different flow conditions. Both the present study, which was part of a more global telemetry experiment to track smolts in the upper Allier River (Tétard et al., 2016), and the observations by Martin et al. (2012) with smolts from the Allier River revealed that strong changes in fish behaviour can occur during the migration season, which has important implications for the design of fish passages.

From a methodological point of view for future telemetry studies involving hatchery fish, the present results highlight the importance of tagging fish at a developmental level in phase with wild individuals and not only in a positive migratory phase. When possible, using wild fish from the same river would ensure that the results are truly representative. However, when this is not possible and hatchery fish have to be used, it is crucial to consider the developmental level of the tagged fish, especially when studying early migrating fish and the effect of stimuli such as light. If this condition is met, hatchery fish may well mimic the behaviour of wild smolts, as previously confirmed (Larinier and Travade, 1999; Nyqvist et al., 2016). Sometimes, apart from methodology, a lack of understanding of the behaviour of the migrating population may impact findings on smolt behaviour close to fishways. This is what happened in the case of the Poutès dam: although the smolts have been videocounted in the bypass for more than 15 years, natural migration timing was always obscured by the delay caused by the reservoir: it was not known that the migration peak was actually one month earlier. Consequently, the previous telemetry experiments studying the effect of lighting on fish behaviour had in fact been conducted on active-swimming fish actually attracted by light (Larinier and BoyerBernard, 1991b).

This represents a great challenge for operating the bypass at the Poutès dam and for other similar dams. There is, however, no evidence that the migration peak and an abrupt switch in smolt behaviour occur every year at the same period in the upper Allier River. The phenomenon could be influenced by several environmental factors such as water temperature and river discharge. We can only cautiously observe that a major shift in smolt behaviour occurs every year, probably around mid-April. The Poutès dam is scheduled to be rebuilt in the coming years to meet ecological continuity requirements, and especially to greatly reduce the delay caused by the reservoir and facilitate the downstream passage of smolts; a bypass lighting protocol should 
no longer be required, since the new bypass design and a much shorter reservoir (reduced from $3 \mathrm{~km}$ to $300 \mathrm{~m}$ long) should hopefully ensure much better guidance by the flow field and quick downstream passage. More generally, in the case of large and deep reservoirs, designing a deeper bypass entrance might be an interesting improvement, which could be tested. If light is an option being considered to enhance attractiveness, sequential lighting would also be an interesting solution to test.

For other river basins, there is no evidence that early migration sparking occurs: this phenomenon may be a local adaptation of an Atlantic salmon population to a very long river system where smolts have to begin their seaward migration much earlier than in smaller basins. For dams located in the upstream part of other long river systems, we would recommend checking the actual timing of migration before designing a bypass or implementing a telemetry experiment.

There is still a great challenge in understanding fish behaviour, which is a key factor in developing effective fish passages (Williams et al., 2012). The influence of environmental stimuli such as light or sound on fish behaviour remains a challenge for the design of upstream and downstream fishways. Attempts to use behavioural barriers to attract or divert fish have had variable success, mostly due to the lack of understanding and quantification of fish behaviour that biologists and engineers still suffer from worldwide (Williams et al., 2012). Experimental approaches to fish behaviour combined with field validations must continue to be conducted.

\section{ACKNOWLEDGMENTS}

The authors state no conflict of interest. We thank the technical team of EDF R\&D for their contribution to the deployment phase. We also thank the CNSS team for their help during catching and tagging sessions. Special thanks to the regional Auvergne Rhône Alpes directorate and the Ecohydraulics pole of the French National Agency for Biodiversity for their great help during hydrophone installation. We thank Iain McGill for professional proofreading of the English text. Finally, we thank EDF GU de Montpezat for letting us access the Poutès dam and conducting this experiment. The study was financially supported by EDF. 


\section{REFERENCES}

AARESTRUP, K. \& KOED, A. 2003. Survival of migrating sea trout ( Salmo trutta) and Atlantic salmon (Salmo salar) smolts negotiating weirs in small Danish rivers. Ecology of Freshwater Fish, 12, 169-176.

ALEXANDER, G., SWEETING, R. \& MCKEOWN, B. 1994. The shift in visual pigment dominance in the retinae of juvenile coho salmon (Oncorhynchus kisutch): an indicator of smolt status. Journal of Experimental Biology, 195, 185-197.

BACH, J. M., LEON, C., PAROUTY, T., DEFOURS, A. \& BAISEZ, A. 2015. Suivi de la dévalaison 2014 des saumoneaux au droit du barrage de Poutès. Saint Pourçain sur Sioule: LOGRAMI.

BAISEZ, A., BACH, J.-M., LEON, C., PAROUTY, T., TERRADE, R., HOFFMANN, M. \& LAFFAILLE, P. 2011. Migration delays and mortality of adult Atlantic salmon Salmo salar en route to spawning grounds on the River Allier, France. Endangered Species Research, 15, 265270.

BERGÉ, J., CAPRA, H., PELlA, H., STEIG, T., OVIDIO, M., BULTEL, E. \& LAMOUROUX, N. 2012. Probability of detection and positioning error of a hydro acoustic telemetry system in a fastflowing river: Intrinsic and environmental determinants. Fisheries Research, 125-126, 1-13.

BRETT, J. R. \& ALI, M. A. 1958. Some observations on the structure and photomechanical responses of the Pacific salmon retina. Journal of the Fisheries Board of Canada, 15, 815-829.

CALENGE, C. 2011. Home range estimation in R: the adehabitatHR package. Office national de la classe et de la faune sauvage: Saint Benoist, Auffargis, France.

CASTRO-SANTOS, T. \& PERRY, R. W. 2012. Time-to-event analysis as a framework for quantifying fish passage performance. Telemetry techniques: a user guide for fisheries research. American Fisheries Society, Bethesda, Maryland, 427-452.

CHANSEAU, M., LARINIER, M. \& TRAVADE, F. 1999. Efficacité d'un exutoire de dévalaison pour smolts de saumon atlantique (Salmo salar L.) et comportement des poissons au niveau de l'aménagement hydroélectrique de Bedous sur le gave d'Aspe étudiés par la technique de marquage-recapture et par radiotélémétrie. Bulletin Français de la Pêche et de la Pisciculture, 353-354, 99-120.

CNSS 2013. Suivi de la dévalaison dans la zone refuge à l'aide de tambours rotatifs à Alleyras et Chanteuges Année 2013. Chanteuges: Conservatoire National du Saumon Sauvage.

CNSS 2014. Suivi de la dévalaison dans la zone refuge à l'aide de tambours rotatifs à Alleyras et Chanteuges. Année 2014. Chanteuges: Conservatoire National du Saumon Sauvage.

CROZE, O. 2008. Assessment of downstream fish bypasses for Atlantic salmon smolts at four hydroelectric facilities on the Ariege River (France). American Fisheries Society Symposium, 61, 123-140.

CROZIER, L. G. \& HUTCHINGS, J. A. 2014. Plastic and evolutionary responses to climate change in fish. Evolutionary Applications, 7, 68-87.

CUINAT, R. 1988. Atlantic Salmon in Extensive French River System: Theb Loire-Allier. Atlantic Salmon. Springer.

DROUINEAU, H., BAU, F., ALRIC, A., DELIGNE, N., GOMES, P. \& SAGNES, P. 2017. Silver eel downstream migration in fragmented rivers: use of a Bayesian model to track movements triggering and duration. Aquatic Living Resources, 30, 5.

ENDERS, E. C., GESSEL, M. H., ANDERSON, J. J. \& WILLIAMS, J. G. 2012. Effects of decelerating and accelerating flows on juvenile salmonid behavior. Transactions of the American Fisheries Society, 141, 357-364.

ENDERS, E. C., GESSEL, M. H. \& WILLIAMS, J. G. 2009. Development of successful fish passage structures for downstream migrants requires knowledge of their behavioural response to 
accelerating flow. Canadian Journal of Fisheries and Aquatic Sciences, 66, 2109-2117.

FERGUSON, J., ABSOLON, R. F., CARLSON, T. J. \& SANDFORD, B. P. 2006. Evidence of Delayed Mortality on Juvenile Pacific Salmon Passing through Turbines at Columbia River Dams. Transactions of the American Fisheries Society, 135, 139-150.

FERNALD, R. D. 1988. Aquatic adaptations in fish eyes. Sensory biology of aquatic animals. Springer.

FOLMAR, L. C. \& DICKHOFF, W. W. 1980. The parr-Smolt transformation (smoltification) and seawater adaptation in salmonids: A review of selected literature. Aquaculture, 21, 1-37.

FRIEDLAND, K. D., MACLEAN, J. C., HANSEN, L. P., PEYRONNET, A. J., KARLSSON, L., REDDIN, D. G., Ó MAOILÉIDIGH, N. \& MCCARTHY, J. L. 2009. The recruitment of Atlantic salmon in Europe. ICES Journal of Marine Science, 66, 289-304.

GARIBALDI, A. \& TURNER, N. 2004. Cultural keystone species: implications for ecological conservation and restoration. Ecology and society, 9, 1.

GESSEL, M. H., WILliAMS, J. G., BREGE, D. A., KRCMA, R. F. \& CHAMBERS, D. R. 1991. Juvenile salmonid guidance at the Bonneville Dam second powerhouse, Columbia River, 19831989. North American Journal of Fisheries Management, 11, 400-412.

GRAHAM, C. T. \& HARROD, C. 2009. Implications of climate change for the fishes of the British Isles. Journal of Fish Biology, 74, 1143-1205.

HAMEL, M. J., BROWN, M. L. \& CHIPPS, S. R. 2008. Behavioral responses of rainbow smelt to in situ strobe lights. North American Journal of Fisheries Management, 28, 394-401.

HANSEN, M. J., COCHERELL, D. E., COOKE, S. J., PATRICK, P. H., SILLS, M. \& FANGUE, N. A. 2018. Behavioural guidance of Chinook salmon smolts: the variable effects of LED spectral wavelength and strobing frequency. Conservation physiology, 6, coy032.

HOAR, W. S., KEENLEYSIDE, M. \& GOODALL, R. G. 1957. Reactions of juvenile Pacific salmon to light. Journal of the Fisheries Board of Canada, 14, 815-830.

IBBOTSON, A. T., BEAUMONT, W. R. C., PINDER, A., WELTON, S. \& LADLE, M. 2006. Diel migration patterns of Atlantic salmon smolts with particular reference to the absence of crepuscular migration. Ecology of Freshwater Fish, 15, 544-551.

ICES 2016. ICES Advice on fishing opportunities, catch and effort. ICES.

ISAAK, D. J., YOUNG, M. K., NAGEL, D. E., HORAN, D. L. \& GROCE, M. C. 2015. The cold-water climate shield: delineating refugia for preserving salmonid fishes through the 21 st century. Global Change Biology, 21, 2540-2553.

IWATA, M. 1995. Downstream migratory behavior of salmonids and its relationship with cortisol and thyroid hormones: A review. Aquaculture, 135, 131-139.

JOHNSON, P. N., BOUCHARD, K. \& GOETZ, F. A. 2005. Effectiveness of strobe lights for reducing juvenile salmonid entrainment into a navigation lock. North American Journal of Fisheries Management, 25, 491-501.

JONSSON, B. \& JONSSON, N. 2004. Factors affecting marine production of Atlantic salmon (Salmo salar). Canadian Journal of Fisheries and Aquatic Sciences, 61, 2369-2383.

JONSSON, B. \& JONSSON, N. 2009. A review of the likely effects of climate change on anadromous Atlantic salmon Salmo salar and brown trout Salmo trutta, with particular reference to water temperature and flow. Journal of Fish Biology, 75, 2381-2447.

KEEFER, M. L., TAYLOR, G. A., GARLETTS, D. F., HELMS, C. K., GAUTHIER, G. A., PIERCE, T. M. \& CAUDILL, C. C. 2012. Reservoir entrapment and dam passage mortality of juvenile Chinook salmon in the Middle Fork Willamette River. Ecology of Freshwater Fish, 21, 222-234.

KEMP, P. S., GESSEL, M. H., SANDFORD, B. P. \& WILLIAMS, J. G. 2006. The behaviour of Pacific salmonid smolts during passage over two experimental weirs under light and dark conditions. River Research and Applications, 22, 429-440.

KEMP, P. S. \& WILLIAMS, J. G. 2009. Illumination influences the ability of migrating juvenile 
salmonids to pass a submerged experimental weir. Ecology of Freshwater Fish, 18, 297-304.

LARINIER, M. 2001. Environmental issues, dams and fish migration. FAO fisheries technical paper, 419, 45-89.

LARINIER, M. \& BOYER-BERNARD, S. 1991a. Dévalaison des smolts et efficacité d'un exutoire de dévalaison à l'usine hydroélectrique d'Halsou sur la Nive. Bulletin Français de la Pêche et de la Pisciculture, 321, 72-92.

LARINIER, M. \& BOYER-BERNARD, S. 1991b. La dévalaison des smolts de Saumon atlantique au barrage de Poutès sur l'Allier (43) : utilisation de lampes à vapeur de mercure en vue d'optimiser l'efficacité de l'exutoire de dévalaison. Bulletin français de la pêche et de la pisciculture, 323, 129-148.

LARINIER, M. \& TRAVADE, F. 1999. The development and evaluation of downstream bypasses for juvenile salmonids at small hydroelectric plants in France. Innovations in fish passage technology, 25.

LARINIER, M. \& TRAVADE, F. 2002. Downstream migration: problems and facilities. Bulletin Français de la Pêche et de la Pisciculture, 364, 181-207.

LE PAPE, O., CHAUVET, F., MAHÉVAS, S., LAZURE, P., GUÉRAULT, D. \& DÉSAUNAY, Y. 2003. Quantitative description of habitat suitability for the juvenile common sole (Solea solea, L.) in the Bay of Biscay (France) and the contribution of different habitats to the adult population. Journal of Sea Research, 50, 139-149.

LIMBURG, K. E. \& WALDMAN, J. R. 2009. Dramatic declines in North Atlantic diadromous fishes. BioScience, 59, 955-965.

LOTZE, H. K. \& MILEWSKI, I. 2004. Two centuries of multiple human impacts and successive changes in a North Atlantic food web. Ecological Applications, 14, 1428-1447.

LUCAS, M. C. \& BARAS, E. 2001. Migration of Freshwater Fishes. John Wiley \& Sons.

MARTIN, P., RANCON, J., SEGURA, G., LAFFONT, J., BOEUF, G. \& DUFOUR, S. 2012. Experimental study of the influence of photoperiod and temperature on the swimming behaviour of hatchery-reared Atlantic salmon (Salmo salar L.) smolts. Aquaculture, 362, 200-208.

MCCORMICK, S. D., HANSEN, L. P., QUINN, T. P. \& SAUNDERS, R. L. 1998. Movement, migration, and smolting of Atlantic salmon (Salmo salar). Canadian Journal of Fisheries and Aquatic Sciences, 55, 77-92.

MCLENNAN, D., RUSH, E., MCKELVEY, S. \& METCALFE, N. 2018. Timing of Atlantic salmon Salmo salar smolt migration predicts successful passage through a reservoir. Journal of Fish Biology, 92, 1651-1656.

MINSTER, A. M. \& BOMASSI, P. 1999. Repérage et évaluation des surfaces potentielles de développement de juvéniles de saumons atlantiques. Proposition d'un modèle de gestion des stocks sur les bassins de l'Allier et de l'Arroux. . LOGRAMI/CSP DR6.

MORITA, K. 2019. Earlier migration timing of salmonids: an adaptation to climate change or maladaptation to the fishery? Canadian Journal of Fisheries and Aquatic Sciences, 76, 475-479.

MOTA, M., ROCHARD, E. \& ANTUNES, C. 2016. Status of the diadromous fish of the Iberian Peninsula: past, present and trends. Limnetica, 35, 1-18.

MUELLER, R. P. \& SIMMONS, M. A. 2008. Characterization of gatewell orifice lighting at the Bonneville Dam second powerhouse and compendium of research on light guidance with juvenile salmonids. Pacific Northwest National Laboratory (PNNL), Richland, WA (US).

NEMETH, R. S. \& ANDERSON, J. J. 1992. Response of juvenile Coho and Chinook salmon to strobe and mercury vapor lights. North American Journal of Fisheries Management, 12, 684-692.

NESTLER, J. M., PLOSKEY, G. R. \& WEEKS, G. 1995. Development of an operational, full-scale fish protection system at a major pumped-storage hydropower dam. American Society of Civil Engineers, New York, NY (United States). 
NETTLES, D. C. \& GLOSS, S. P. 1987. Migration of landlocked Atlantic salmon smolts and effectiveness of a fish bypass structure at a small-scale hydroelectric facility. North American Journal of Fisheries Management, 7, 562-568.

NOONAN, M. J., GRANT, J. W. \& JACKSON, C. D. 2012. A quantitative assessment of fish passage efficiency. Fish and Fisheries, 13, 450-464.

NÚÑEZ-RODRÍGUEZ, J., VELA DÍAZ, A., BAZAN-ALBITEZ, R., REBAZA ALFARO, C., KOUA, D., NÚÑEZ, L., TESTI, B., RENNO, J., DUPONCHELLE, F. \& PELLA, H. 2018. Use of an acoustic telemetry array for fine scale fish behaviour assessment of captive Paiche, Arapaima gigas, breeders. Aquaculture Research, 49, 2296-2304.

NYQVIST, D., ELGHAGEN, J., HEISS, M. \& CALLES, O. 2018. An angled rack with a bypass and a nature-like fishway pass Atlantic salmon smolts downstream at a hydropower dam. Marine and Freshwater Research, 69, 1894-1904.

NYQVIST, D., GREENBERG, L. A., GOERIG, E., CALlES, O., BERGMAN, E., ARDREN, W. R. \& CASTRO-SANTOS, T. 2016. Migratory delay leads to reduced passage success of Atlantic salmon smolts at a hydroelectric dam. Ecology of Freshwater Fish, 26, 707-718.

NYQVIST, D., MCCORMICK, S., GREENBERG, L., ARDREN, W., BERGMAN, E., CALLES, O. \& CASTRO-SANTOS, T. 2017. Downstream Migration and Multiple Dam Passage by Atlantic Salmon Smolts. North American Journal of Fisheries Management, 37, 816-828.

OKAMURA, B., HARTIKAINEN, H., SCHMIDT-POSTHAUS, H. \& WAHLI, T. 2011. Life cycle complexity, environmental change and the emerging status of salmonid proliferative kidney disease. Freshwater Biology, 56, 735-753.

OVIDIO, M., DIERCKX, A., BUNEL, S., GRANDRY, L., SPRONCK, C. \& BENITEZ, J.-P. 2017. Poor performance of a retrofitted downstream bypass revealed by the analysis of approaching behaviour in combination with a trapping system. River Research and Applications, 33, 27-36.

PERRY, R. W., ROMINE, J. G., ADAMS, N. S., BLAKE, A. R., BURAU, J. R., JOHNSTON, S. V. \& LIEDTKE, T. L. 2014. Using a non-physical behavioural barrier to alter migration routing of juvenile Chinook salmon in the Sacramento-San Joaquin River delta. River Research and Applications, 30, 192-203.

PLOSKEY, G. R., NESTLER, J. M. \& WEEKS, G. 1995. Evaluation of an integrated fish-protection system. American Society of Civil Engineers, New York, NY (United States).

PORCHER, J.-P. \& TRAVADE, F. 1992. Les dispositifs de franchissement: bases biologiques, limites et rappels réglementaires. Bulletin Français de la Pêche et de la Pisciculture, 326-327, 5-14.

PRACHEIL, B. M., DEROLPH, C. R., SCHRAMM, M. P. \& BEVELHIMER, M. S. 2016. A fish-eye view of riverine hydropower systems: the current understanding of the biological response to turbine passage. Reviews in Fish Biology and Fisheries, 26, 153-167.

R DEVELOPMENT CORE TEAM 2018. R: A language and environment for statistical computing. $R$ Foundation for Statistical Computing, Vienna, Austria.

RILEY, W. D., BENDALL, B., IVES, M. J., EDMONDS, N. J. \& MAXWELL, D. L. 2012. Street lighting disrupts the diel migratory pattern of wild Atlantic salmon, Salmo salar L., smolts leaving their natal stream. Aquaculture, 330, 74-81.

ROSCOE, D. W. \& HINCH, S. G. 2010. Effectiveness monitoring of fish passage facilities: historical trends, geographic patterns and future directions. Fish and Fisheries, 11, 12-33.

ROY, R., BEGUIN, J., ARGILLIER, C., TISSOT, L., SMITH, F., SMEDBOL, S. \& DE-OLIVEIRA, E. 2014. Testing the VEMCO Positioning System: spatial distribution of the probability of location and the positioning error in a reservoir. Animal Biotelemetry, 2, 1-7.

SCRUTON, D. A., MCKINLEY, R. S., KOUWEN, N., EDDY, W. \& BOOTH, R. K. 2003. Improvement and optimization of fish guidance efficiency (FGE) at a behavioural fish protection system for downstream migrating Atlantic salmon (Salmo salar) smolts. River Research and 
Applications, 19, 605-617.

SEGURADO, P., BRANCO, P., AVELAR, A. P. \& FERREIRA, M. T. 2015. Historical changes in the functional connectivity of rivers based on spatial network analysis and the past occurrences of diadromous species in Portugal. Aquatic Sciences, 77, 427-440.

SILVA, A. T., LUCAS, M. C., CASTRO-SANTOS, T., KATOPODIS, C., BAUMGARTNER, L. J., THIEM, J. D., AARESTRUP, K., POMPEU, P. S., O'BRIEN, G. C. \& BRAUN, D. C. 2018. The future of fish passage science, engineering, and practice. Fish and Fisheries, 19, 340-362.

STRØM, J. F., THORSTAD, E. B., HEDGER, R. D. \& RIKARDSEN, A. H. 2018. Revealing the full ocean migration of individual Atlantic salmon. Animal Biotelemetry, 6, 2.

SWANSON, C., YOUNG, P. S. \& CECH JR, J. J. 2004. Swimming in two-vector flows: performance and behavior of juvenile Chinook salmon near a simulated screened water diversion. Transactions of the American Fisheries Society, 133, 265-278.

TENTELIER, C. \& PIOU, C. 2011. Obstacles to migration constrain nest distribution of Atlantic salmon. Ecology of Freshwater Fish, 20, 400-408.

TÉTARD, S., LEMAIRE, M., DE OLIVEIRA, E. \& MARTIN, P. Use of 2D acoustic telemetry to study the behaviour of atlantic salmon smolts (Salmo salar) approaching Poutès Dam (Allier River, France). Proceedings of the 11 ${ }^{\text {th }}$ International Symposium on Ecohydraulics, 7-12 February 2016. The University of Melbourne, Australia.

THORSTAD, E. B., ØKLAND, F., AARESTRUP, K. \& HEGGBERGET, T. G. 2008. Factors affecting the within-river spawning migration of Atlantic salmon, with emphasis on human impacts. Reviews in Fish Biology and Fisheries, 18, 345-371.

THORSTAD, E. B., WHORISKEY, F., RIKARDSEN, A. H. \& AARESTRUP, K. 2011. Aquatic nomads: the life and migrations of the Atlantic salmon. Atlantic Salmon Ecology, 1, 6.

TODD, C. D., HUGHES, S. L., MARSHALL, C., MACLEAN, J. C., LONERGAN, M. E. \& BIUW, E. 2008. Detrimental effects of recent ocean surface warming on growth condition of Atlantic salmon. Global Change Biology, 14, 958-970.

TOMANOVA, S., COURRET, D. \& ALRIC, A. 2017. Protecting fish from entering turbines: the efficiency of a low-sloping rack for downstream migration of Atlantic salmon smolts. La Houille Blanche, 11-13.

TOMANOVA, S., COURRET, D., ALRIC, A., DE OLIVEIRA, E., LAGARRIGUE, T. \& TÉTARD, S. 2018. Protecting efficiently sea-migrating salmon smolts from entering hydropower plant turbines with inclined or oriented low bar spacing racks. Ecological Engineering, 122, 143-152.

VERSPOOR, E., STRADMEYER, L. \& NIELSEN, J. L. 2008. The Atlantic salmon: genetics, conservation and management, John Wiley \& Sons.

VOWLES, A. S., ANDERSON, J. J., GESSEL, M. H., WILLIAMS, J. G. \& KEMP, P. S. 2014. Effects of avoidance behaviour on downstream fish passage through areas of accelerating flow when light and dark. Animal Behaviour, 92, 101-109.

VOWLES, A. S. \& KEMP, P. S. 2012. Effects of light on the behaviour of brown trout (Salmo trutta) encountering accelerating flow: Application to downstream fish passage. Ecological Engineering, 47, 247-253.

WILLIAMS, J. G., ARMSTRONG, G., KATOPODIS, C., LARINIER, M. \& TRAVADE, F. 2012. Thinking like a fish: a key ingredient for development of effective fish passage facilities at river obstructions. River Research and Applications, 28, 407-417.

WINTER, J. 1996. Advances in underwater biotelemetry. Fisheries techniques, $2^{\text {nd }}$ edition. American Fisheries Society, Bethesda, Maryland, 555-590. 


\section{APPENDICES}

APPENDIX A.1: Cumulative rates of detected fish (individuals) in the approach zone (upper panel), of detections (positions) in the approach zone (middle panel) and of tagged smolts released upstream of the Poutès reservoir (lower panel). Vertical dashed line indicates the date of $15^{\text {th }}$ April.
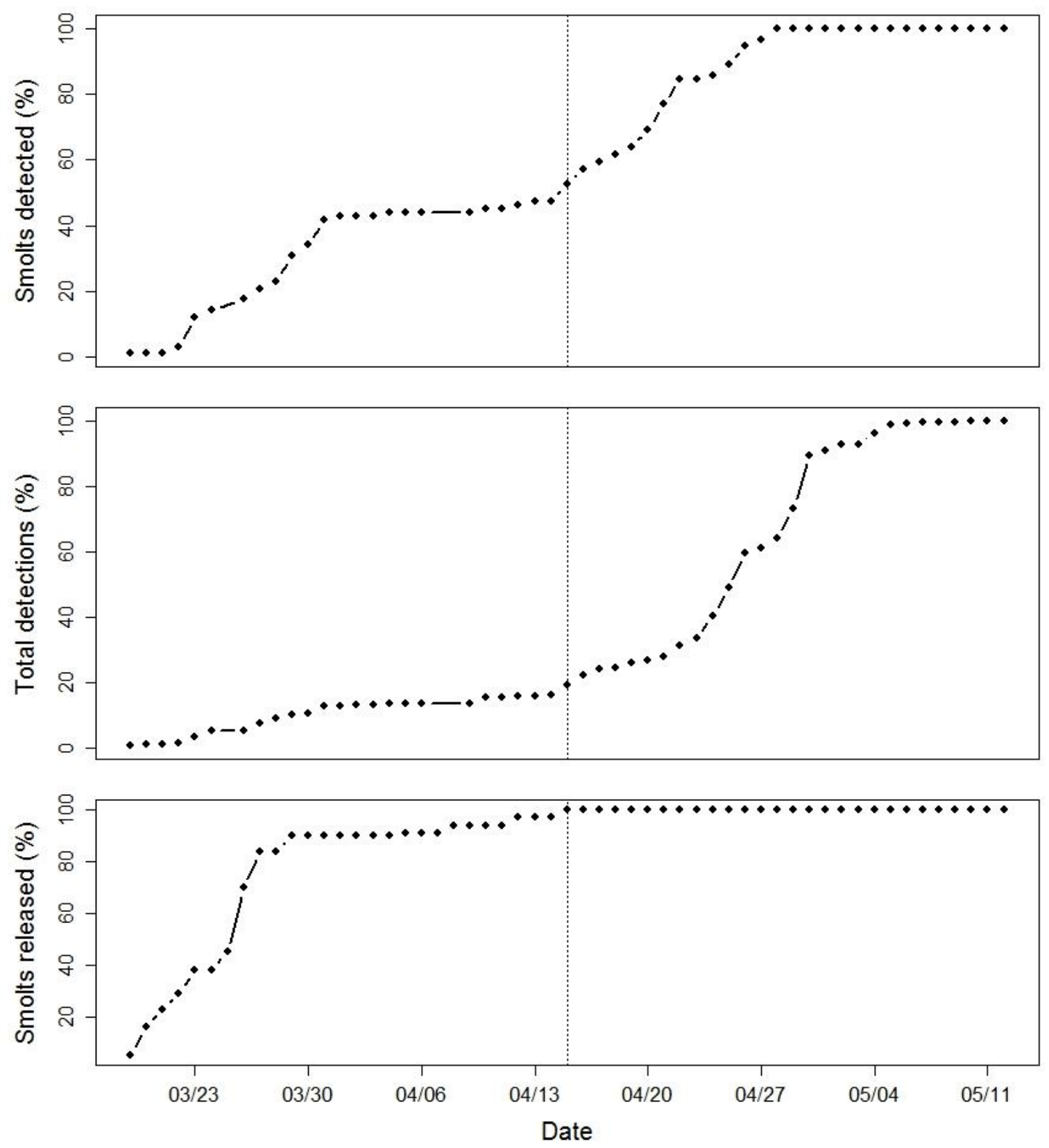
APPENDIX A.2: Aerial view of the Poutès dam (top), side view of the bypass entrance (bottom left) and front view of the intake and bypass entrance (bottom right).
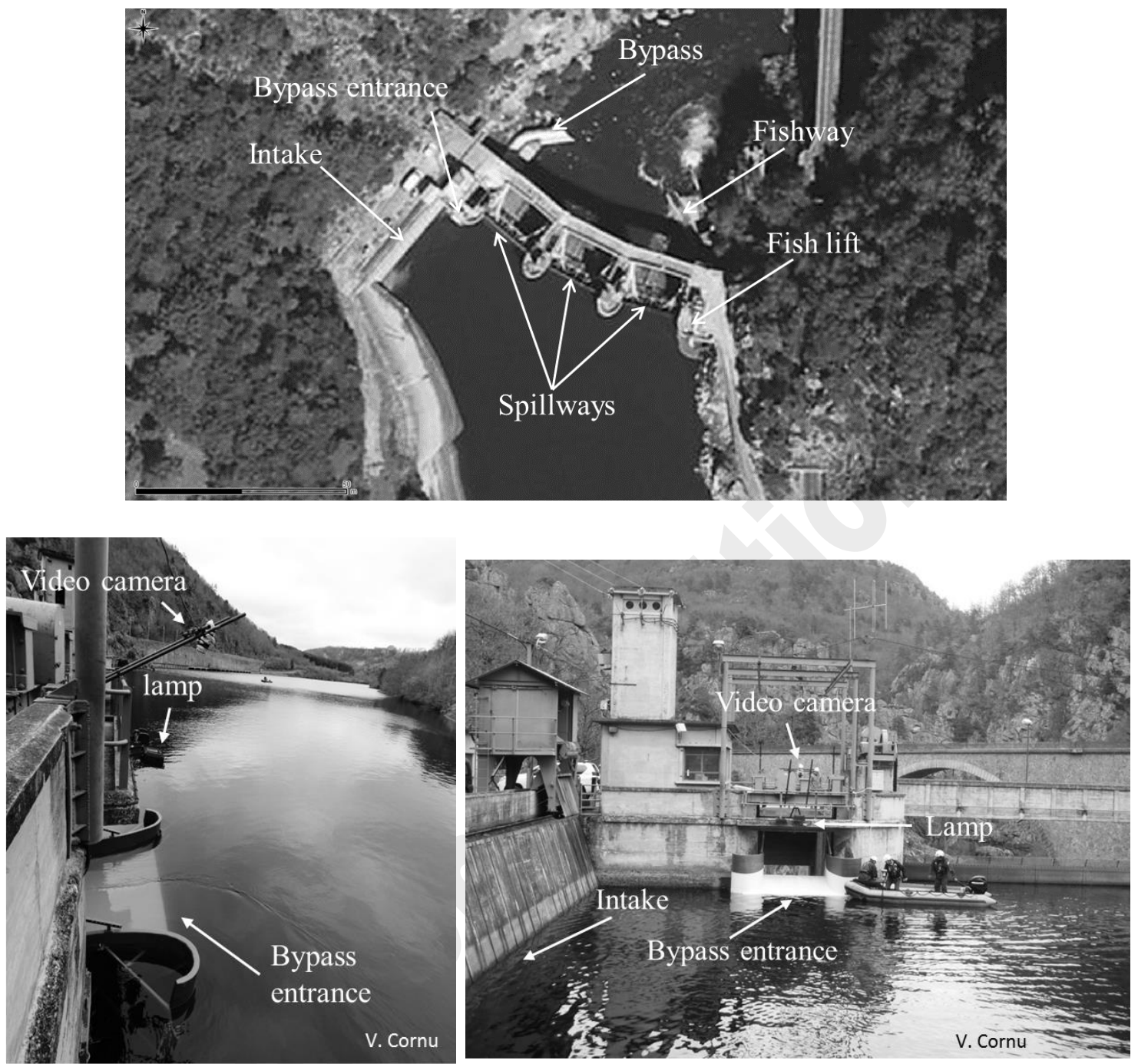
APPENDIX A.3: Sensitivity analysis of the mean number of nocturnal attempts in the approach zone per smolt and per attempt in the dam zone in each configuration of lighting and period in the migration season. The various dimensions of the approach zone tested are represented in the upper panel. Boxplots of the mean number of nocturnal attempts in the approach zone under the different configurations for each dimension of the approach zone are shown in the lower panel. White and grey boxes correspond to entrance lighting switched on or off, respectively.
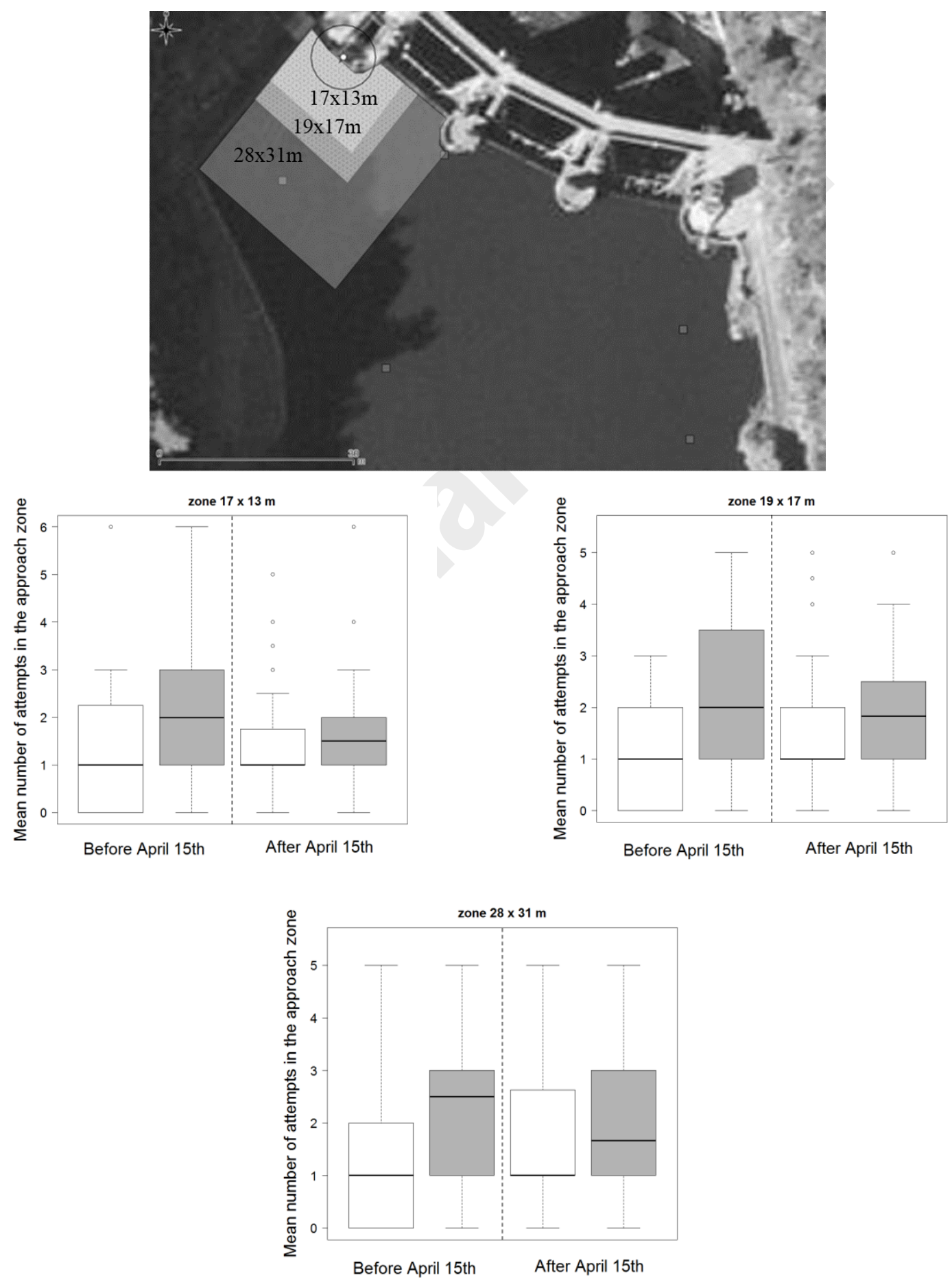